\title{
A global review of green turtle diet: sea surface temperature as a potential driver of omnivory levels
}

\author{
Nicole Esteban ${ }^{1}$ D . Jeanne A. Mortimer ${ }^{2,3} \cdot$ Holly J. Stokes $^{1} \cdot$ Jacques-Olivier Laloë ${ }^{4}$ Richard K. F. Unsworth ${ }^{1}$. \\ Graeme C. Hays ${ }^{4}$
}

Received: 19 July 2019 / Accepted: 13 October 2020 / Published online: 16 November 2020

(c) The Author(s) 2020

\begin{abstract}
To better understand dietary requirements, trophic shifts, and trophic interactions of the threatened green turtle (Chelonia mydas), we conducted a comprehensive global review and literature tabulation (177 studies) reporting diets of individuals $>25 \mathrm{~cm}$ carapace length. We analysed those studies involving natural sites and healthy animals that reported relative proportions of all diet components (67 studies, 89 datasets at 75 sites, 13 geographic sub-regions, 3 oceans). We compared diets by sub-region and foraging site relative to four diet components, i.e., seagrass, macroalgae, terrestrial plants (including mangroves) and animal matter. To assess sea surface temperature (SST) as an environmental driver, values were extracted from satellite data (single year) and site-specific observations (study durations) and examined relative to diet composition. Satellite data indicated that at warmer sites with temperatures $>25^{\circ} \mathrm{C}(\geq 6$ months annually), diet was predominantly herbivorous (mean $=92.97 \%$; $\mathrm{SE}=9.85 ; n=69$ datasets). At higher latitude sites and in cold-water currents with SST $<20^{\circ} \mathrm{C}$ ( $\geq 6$ months annually), dietary animal matter featured prominently (mean $=51.47 \%$; $\mathrm{SE}=4.84 ; n=20$ datasets). Site-specific observations indicated that SST had a small but significant effect on contributions of animal matter $\left(r^{2}=0.17, P=<0.001\right)$ and seagrass $\left(r^{2}=0.24, P=<0.001\right)$ but not macroalgae and terrestrial plants. Our study presents the first quantitative evidence at a global scale that temperature may be an important driver of omnivory, providing a new perspective on variations in green turtle diet, especially in light of global warming and climate change.
\end{abstract}

Responsible Editor: P. Casale.

Reviewed by undisclosed experts.

Electronic supplementary material The online version of this article (https://doi.org/10.1007/s00227-020-03786-8) contains supplementary material, which is available to authorized users.

Nicole Esteban

n.esteban@swansea.ac.uk

1 Department of Biosciences, Swansea University, Swansea, Wales SA2 8PP, UK

2 Department of Biology, University of Florida, Gainesville, FL 32611, USA

3 P.O. Box 1443, Victoria, Mahé, Republic of Seychelles

4 Centre for Integrative Ecology, Deakin University, Geelong, VIC, Australia

\section{Introduction}

Dietary studies are vital to understanding the ecological role of organisms and their trophic interactions (Duffy et al. 2007), which for large marine vertebrates are often not well understood (Matich et al. 2011). Moreover, a better understanding of dietary requirements may help resource managers respond to shifts in trophic interactions between taxa (Brodeur et al. 2017) and, for sea turtles, more effectively prioritize conservation zones and policies for foraging grounds (Hamann et al. 2010; Rees et al. 2016).

Due to numerous anthropogenic threats and population declines, the green turtle (Chelonia mydas) was previously listed as globally Endangered on the IUCN Red List (Seminoff 2004). Successful conservation strategies, such as protection of nesting turtles and nesting and foraging habitats, have led to long-term population recovery at many sites (Chaloupka et al. 2008; Mazaris et al. 2017; Silva et al. 2017; Mortimer et al. 2020), resulting in IUCN downlisting of various green turtle subpopulations (e.g., Broderick and Patricio 2019). While sea turtles are particularly vulnerable 
at their breeding grounds which are easily accessible to humans, they spend most of their lives at their foraging grounds (Hays et al. 2014). Green turtles can migrate vast distances across international borders between breeding and feeding grounds (Hays and Hawkes 2018; Hays et al. 2020) and maintain tight fidelity to their foraging grounds over successive migrations (Shimada et al. 2020). These complex life history strategies highlight the need to improve understanding of green turtle foraging behaviour in different regions and habitats (Klein et al. 2017).

Turtle diet composition can be assessed by a variety of techniques (Jones and Seminoff 2013). Traditional methods include direct observation using snorkel or SCUBA (Reisser et al. 2013), the analysis of gut contents from dead turtles (Mortimer 1981) and oesophageal lavage and faecal examination (Seminoff et al. 2002), while indirect biochemical approaches include stable isotope analysis (SIA) (Pearson et al. 2017). Modern technologies, such as remote videography (Letessier et al. 2014), animal-borne cameras (Heithaus et al. 2002), autonomous underwater vehicles (Dodge et al. 2018) as well as satellite tracking from nesting beach and subsequent in situ validation of diet at foraging locations (Esteban et al. 2018), have also been used to document the activities of turtles at their foraging habitats.

The green turtle has been associated with seagrass meadows beginning with early observations in the Indian Ocean (Frazier 1971; Hirth et al. 1973) and long-term studies in the Caribbean (e.g., Bjorndal 1980; Mortimer 1981; Vander Zanden et al. 2013) that reported a herbivorous diet dominated by seagrasses. This seagrass diet is thought to have the wider functional role of supporting seagrass ecosystem resilience (Christianen et al. 2019). Post-hatchling green turtles are believed to spend their first 3-10 years, depending on the ocean basin (Reich et al. 2007; Arthur et al. 2008), in open ocean pelagic habitat and then typically recruit to neritic habitats where their diets tend to shift from omnivorous to primarily herbivorous (see Jones and Seminoff 2013; Howell et al. 2016; Vélez-Rubio et al. 2016; Burgett et al. 2018). Recruitment size (based on curved carapace length (CCL)) varies across populations from $20-25 \mathrm{~cm}$ in the western Atlantic (Bjorndal and Bolten 1988) to $30-35 \mathrm{~cm}$ in the Indo-Pacific (Limpus et al. 1994) and $30-45 \mathrm{~cm}$ in the southwestern Pacific (Arthur et al. 2008) and north central Pacific (Parker et al. 2011).

Seagrasses dominate the diet of green turtles at a range of sites across the Mediterranean (Margaritoulis and Teneketzis 2003; Cardona et al. 2010; Karaa et al. 2012), Indian Ocean (Hasbún et al. 2000; Whiting et al. 2007; Stokes et al. 2019) and Pacific Ocean (Limpus and Reed 1985; Arthur et al. 2009; Prior et al. 2016). At foraging sites where seagrass is absent or sparse, green turtle diet is supplemented or dominated by macroalgae, for example, in Japan (Shimada et al. 2014), Queensland, Australia (Garnett et al. 1985; Prior et al. 2016), Cocos-Keeling Islands (Whiting et al. 2014), Mexico (López-Mendilaharsu et al. 2005), Turkey (Özdilek et al. 2015), and Uruguay (Darré Castell et al. 2005). Terrestrial plant material, especially mangrove leaves and propagules, can also feature prominently in green turtle diets at some sites (Arthur et al. 2009; Nagaoka et al. 2012). Although green turtles are primarily herbivorous, reports of a wide ranging diet of seagrass, marine algae and invertebrates (Jones and Seminoff 2013) include purposely ingested animal matter, such as gelatinous macrozooplankton (e.g., scyphozoan jellyfish and salps), sponges, molluscs and fish (Mortimer 1981; Bjorndal 1997; Burkholder et al. 2011; Fukuoka et al. 2019; Piovano et al. 2020).

Studies in the eastern Pacific (Etnoyer et al. 2006), the Mediterranean (Cardona et al. 2010) and in the southwestern Atlantic (Santos et al. 2015) have suggested a relationship between green turtle omnivory levels and sea surface temperature (SST). Nevertheless, regional variations in diet, and the possible role of SST as a driver of these variations have not been examined at a global scale. Here, we investigate the diet of green turtles greater than $25 \mathrm{~cm}$ CCL (i.e. beyond the presumed 3-10 year-long post-hatchling pelagic stage) in various parts of the world. Specifically, we (1) reviewed literature to assess variation and patterns in the diets of immature and adult green turtles from foraging sites around the globe; (2) analysed the relationship between SST and diet globally to assess SST as a potential driver of omnivory; and (3) examined other possible drivers of green turtle diet that we encountered in the literature. The results of our study will provide a better understanding of diet variation across oceans and help guide green turtle conservation management especially in the context of global warming.

\section{Materials and methods}

\section{Global review of green turtle diet}

We conducted a literature search in April 2020 for papers of 'All document types' and 'All languages' on Web of Science using the search terms: ALL $=$ (green turtle* OR Chelonia mydas) AND ALL $=\left(\operatorname{diet}^{*}\right.$ OR forag*) and Google Scholar using the search terms: TOPIC ('green turtle*' OR 'Chelonia mydas') AND ('diet*' OR 'forag*'). Literature citations in the most recent and comprehensive articles located were then checked for studies of green turtle diet; in many cases, these involved grey literature that might have been missed by Web of Science or Google Scholar searches. We worked our way back through historical literature in this manner until no more studies reporting diet could be found.

To produce our global review of green turtle diet, we excluded studies of green turtles with carapace length $<25 \mathrm{~cm}$ CCL (e.g., Boyle and Limpus 2008) on the 
assumption that they represented the 3-10-year-old posthatchling pelagic life stage. We also excluded diet studies if they did not report the relative proportion of all dietary components (e.g. Russell and Balazs 2009) or were from a large-scale pelagic fishery with unknown foraging location (e.g., Parker et al. 2011; Wedemeyer-Strombel et al. 2015). Studies of turtles that were diseased or stranded were excluded due to potential bias in diet as were those of unknown foraging location (e.g., Riosmena-Rodriguez et al. 2011; Souza 2019). We excluded diet studies of captive or artificially fed turtles (e.g., Monzón-Argüello et al. 2018), along with data describing the diets of gravid female green turtles which can differ significantly from those of males, non-breeding females and immature turtles even at shared foraging habitat (Stokes et al. 2019). Where multiple studies from the same site utilised the same dataset, the most detailed study was included (e.g., Arthur et al. 2009; not Arthur et al. 2006). Excluded studies were compiled and reasons for their exclusion provided (Online Resource 1 Table S2).

Where there was no significant difference in diet between multiple sites in one study, data were presented for a centrally located site (e.g., Arthur and Balazs 2008; Stokes et al. 2019). Many of the studies we reviewed did not distinguish size classes, and did not report diet data for immature and adult individuals separately, especially when both occurred together at a benthic foraging site (e.g., Forbes 1996; Read and Limpus 2002; Prior et al. 2016). We, therefore, pooled our findings on the diet for both immature ( $>25 \mathrm{~cm} \mathrm{CCL}$ ) and adult breeding turtles.

In our global review, we recorded the methodologies employed by each study, i.e., gut content analysis, oesophageal lavage, SIA, etc., and tabulated the proportions of individual diet items encountered. We converted results from animal-borne camera studies to diet proportion by dividing the number of bites or feeding events for a diet item (e.g. seagrass) by the total number of bites or feeding events for all diet items. We assigned each type of diet item to one of six categories. The four key nutritional categories were: seagrass, macroalgae, terrestrial plants (e.g., fruits and leaves of mangroves Avicennia marina, A. schaueriana, A. germinans, Rhizophora mangle and saltmarsh Spartina alterniflora; leaves of Ficus spp, Hibiscus spp, Ochroma spp), and animal matter. The fifth and sixth categories were anthropogenic debris (e.g., plastic fibre) and 'other'. The category 'other' was not always defined in studies but, where defined, included substrate (sand, shell, stone), very digested material, unidentifiable material and natural debris (e.g., bird feathers, wood fragments, etc.). We overlaid green turtle diet composition as defined by the six categories onto a world map shapefile (Made with Natural Earth) using QGIS v3.0, including the available global seagrass distribution (UNEPWCMC and Short 2018) for reference.
We organized the global diet studies into geographic subregions (Online Resource 1 Tables S1-2) based on maps produced by Wallace et al. (2010) to define the global distribution of regional management units (RMUs) of green turtles. An RMU comprises a breeding unit of turtles above the level of the nesting populations but below the level of species within a sub-region, and the RMU maps roughly indicate the distribution of animals belonging to an RMU breeding unit. For our purposes, the geographic boundaries defined by these RMU maps (excluding some areas of overlap) provided objective criteria with which to organize and then compare global studies of turtle diet by sub-region, including all diet data collected for both adults and immature turtles within each sub-region. Our 13 sub-regions corresponded with the following 13 map-defined RMUs (Wallace et al. 2010): Pacific North Central, Pacific East, Atlantic North West, Atlantic South West, Atlantic East, Mediterranean, Indian South West, Indian North West, Indian North East, Indian South East, Pacific South West, Pacific South Central, and Pacific North West. Figure 1a provides a map of the 13 sub-regions and their abbreviations.

\section{Relationship between green turtle diet and SST}

We assessed the relationship between green turtle diet and SST at two spatial resolutions. First, we used a global scale satellite-sourced SST dataset to present a visual overview. We then used in situ surface observations of SST from the International Comprehensible Ocean-Atmosphere Data Set (ICOADS) to obtain higher-resolution coastal SST data for each foraging site for fine-scale analysis.

\section{Global SST overview}

To produce a visual global overlay map of SST at each of the study sites included in this study, global day-night monthly SST averages, during a single year, derived from the AVHRR Pathfinder (Version 5, $4 \mathrm{~km}$ ) SST cloud screened dataset (Phillips et al. 2012) were downloaded and projected on ArcMap version 10.5.1. Although accuracy and precision of satellite-sourced SST at the coastline is lower than SST measurements made in situ (Brewin et al. 2018), this dataset was used for the global overview as it provides the longest, accurate and highest-resolution SST climate data record for analysis of global SST (NCAR 2014). The dataset was not available for the entire time series. We selected the year 1993 for two reasons: it represents the midpoint of the sampling period for the diet studies (1971-2016); and it lacked El Niño and La Niña events (NOAA 2020). Quarterly periods (Jan-Mar, Apr-Jun, Jul-Sep, Oct-Dec) were selected to represent seasonal variation in temperature at different sites. 


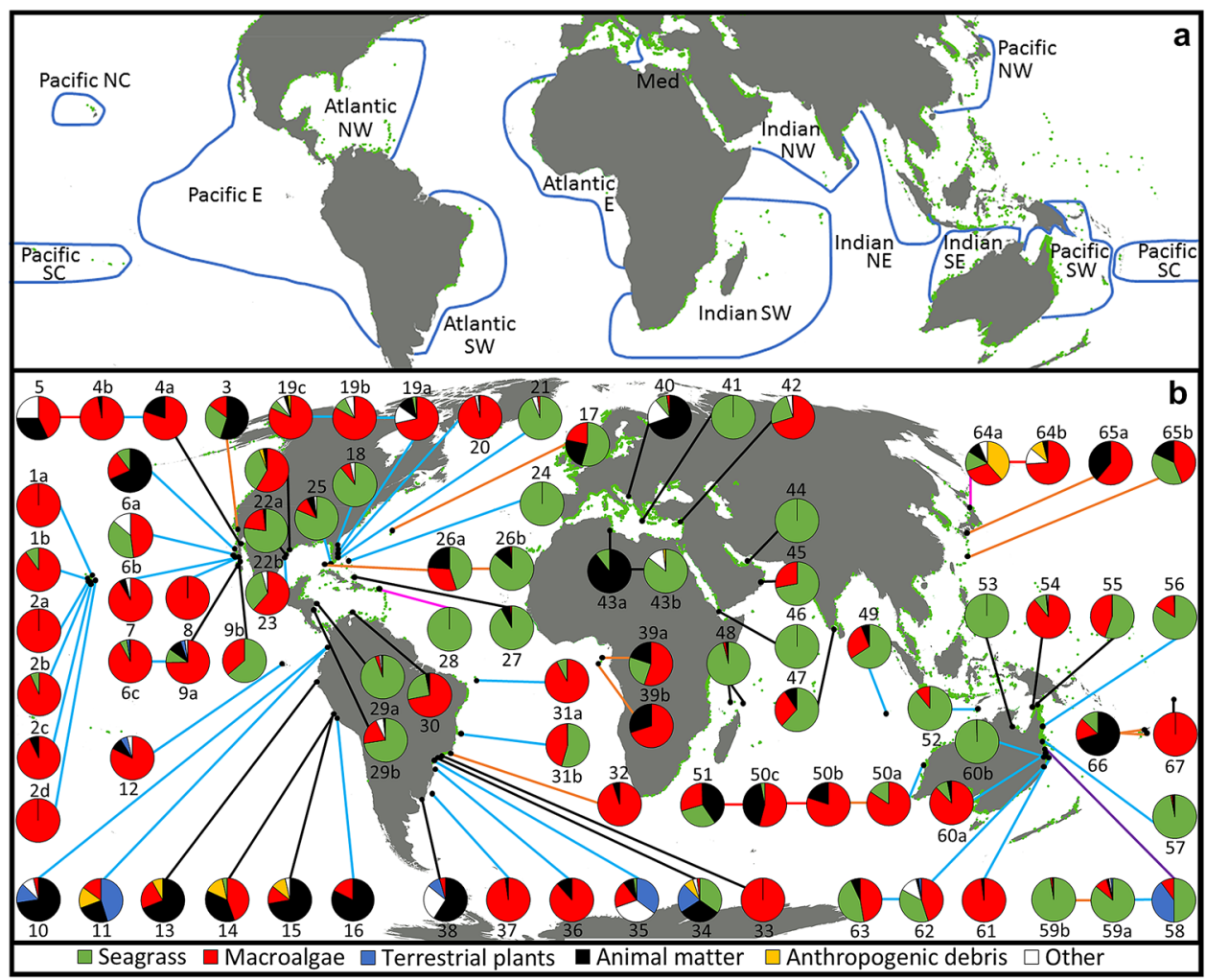

Fig. 1 Comparison of green turtle diet composition across the globe. a 13 geographic sub-regions, based on maps of the Chelonia mydas RMUs (adapted from Wallace et al. 2010), were used to compare diet composition. Moving from west to east these include: Pacific North Central (Pacific NC), Pacific East (Pacific E), Atlantic North West (Atlantic NW), Atlantic South West (Atlantic SW), Atlantic East (Atlantic E), Mediterranean (Med), Indian South West (Indian $\mathrm{SW}$ ), Indian North West (Indian NW), Indian North East (Indian NE), Indian South East (Indian SE), Pacific South West (Pacific SW), Pacific North West (Pacific NW), Pacific South Central (Pacific SC). b The proportions of contribution made by each of six categories of diet items recorded in 89 datasets at 75 sites are shown by segments of the pie charts. The term 'Other' is not always defined and includes

\section{Foraging site SST}

We extracted in situ observations of SST data for the $1^{\circ}$ by $1^{\circ}$ pixel around each foraging site from ICOADS (NCAR 2015). We obtained data from the Enhanced ICOADS Monthly Summary Release 3.0 at the 1-degree spatial resolution for the 12 months, from January to December that coincided with the sampling period of each respective study, e.g., if sampling took place in 2005 and 2006, then SST data were included from January 2005 through December 2006. There are fewer sites included in the analysis of SST at foraging sites than in the global SST overview. This is because we avoided potential bias due to under-sampling by excluding those seven datasets with $<10$ SST observations per month. Some of these datasets were for the same site and three sites were excluded from further analysis because substrate, very digested material, and natural debris (e.g., feathers). Methods used to study diet are represented by coloured lines-i.e., gut content analysis (black), oesophageal lavage (blue), SIA (orange), mouth content (purple), faecal examination (pink) and animal-borne camera (red) studies. Green dots indicate known seagrass observation data points (Source: UNEP-WCMC and Short, 2018, see Online Resource 1 Fig. S1-S4 for fine-scale maps). Numbers indicate source literature (see Online Resource 1 Table S1 for study site, analytical method, diet group and results), and break-down by sub-region as follows: Pacific NC (1-2), Pacific E (3-16), Atlantic NW (17-30), Atlantic SW (31-38), Atlantic E (39), Med (40-43), Indian NW (4447), Indian SW (48), Indian NE (49), Indian SE (50-52), Pacific SW (53-63), Pacific NW (64-65), and Pacific SC (66-67)

SST data were unavailable, i.e., South Caribbean Nicaragua, Torres Strait Australia, and Tokelau. Multiple diet composition datasets existed across several sampling periods at some sites, e.g., Bahia de los Angeles, Mexico and Shark Bay, Australia, and are included in the analysis. We calculated the mean annual SST, the maximum annual SST and the minimum annual SST for each site.

\section{Data analysis}

The average contribution of each of the six major dietary components of green turtle diet (seagrass, macroalgae, terrestrial plants, animal matter, other, and anthropogenic debris) was compared using a Kruskal-Wallis rank-sum test. To compare diet across sub-regions, a Dunn's (1964) test was used to calculate multiple comparison $p$-values 
adjusted with the Benjamini and Hochberg (1995) method. For the foraging site SST analysis, dietary component data were arcsine-square-root-transformed. Linear regression was used to explore the relationship between diet content data and SST at foraging sites. Figures are presented showing untransformed (Figs. 1-3) or back-transformed data (Fig. 4; Online Resource Fig. S5) for ease of interpretation. Statistical analyses were performed using $\mathrm{R}$ (R Core Team 2017). Mean \pm SE values are presented unless otherwise indicated. The significance level of all statistical tests was set at $\alpha<0.05$.

\section{Results}

\section{Global review of green turtle diet}

Of the 177 articles examined, 67 articles with 89 datasets describing diet composition of green turtles at 75 sites around the world met the criteria for inclusion in our review (Fig. 1; Online Resource Table S1). An additional 110 diet studies were excluded from further analysis for the following reasons: unspecified diet composition $(n=40)$ or foraging location $(n=7)$; sampling of stranded dead/diseased individuals $(n=28)$, captive turtles with artificially fed diet $(n=11)$, or nesting females $(n=3)$; focus on ingestion of anthropogenic debris $(n=17)$; turtles below minimum carapace size $(n=2)$; or duplicate dataset $(n=2)$. See Online Resource 1 Table S2 for study details and exclusion reasons.

The datasets in studies that met our criteria spanned 13 sub-regions in 3 oceans and 1 sea: Pacific N Central (Hawaii) ( $n=6)$, Pacific E (off North, Central and South America) $(n=18)$, Atlantic NW (off North and Central America, including Caribbean) $(n=19)$, Atlantic SW (off South America) $(n=9)$, Atlantic E (São Tomé Island) $(n=2)$, Mediterranean $(n=5)$, Indian NW (Arabian Peninsula and India) $(n=4)$, Indian SW (Seychelles) $(n=1)$, Indian NE (Cocos-Keeling) $(n=1)$, Indian SE (Western Australia) ( $n=5)$, Pacific SW (Eastern Australia) $(n=13)$, Pacific NW (Japan) $(n=4)$ and Pacific S Central (Fiji and Tokelau) $(n=2)$. The relative prominence of the following four key nutritional categories was reported across sites and is considered in our analysis: seagrass, macroalgae, terrestrial plants, and animal matter. The amount of anthropogenic debris in the diet also varies between sites. Nevertheless, some patterns emerge (Figs. 1 and 2). An expanded version of Fig. 1 (Online Resource 1 Figs. S1-4) shows details of regional seagrass distribution as well as contribution of the six categories of diet items.

Seagrass dominant. Seagrass contribution to diet is greatest in the following sub-regions: Indian SW (mean $=95.0 \% ; n=1$; Stokes et al. 2019), Indian NW (mean $=83.3 \%$; SE =9.6; $n=4$; e.g., Hasbún et al. 2000),
Indian NE $($ mean $=65.1 \% ; n=1$; Whiting et al. 2014), Pacific SW (mean $=59.3 \%$; SE $=10.4 ; n=13$; e.g., Fuentes et al. 2006; Prior et al. 2016), Atlantic NW (mean $=57.5 \%$; $\mathrm{SE}=8.2 ; n=19$; e.g., Mortimer 1981; Stringell et al. 2016) and Mediterranean (mean $=46.0 \%$; $\mathrm{SE}=19.4 ; n=5$; e.g., Karaa et al. 2012). All studies that recorded no seagrass (or virtually none) in the diet are from regions with limited documented seagrass distribution (e.g., Pacific E and Atlantic SW) (Fig. 1; Online Resource 1 Figs. S1-S4).

Macroalgae dominant. Macroalga is consumed most abundantly in the following sub-regions: Pacific N Central (mean $=96.0 \%$; $\mathrm{SE}=1.9 ; n=6$; e.g., Arthur and Balazs 2008; Balazs et al. 1987), Atlantic $\mathrm{E}($ mean $=62.5$; $\mathrm{SE}=7.5 ; n=2$; e.g., Hancock et al. 2018), Atlantic SW (mean $=59.5 \% ; \mathrm{SE}=13.9 ; n=9$ ) especially tropical areas (e.g., Reisser et al. 2013), Pacific S Central (mean $=58.5$; $\mathrm{SE}=41.5 ; n=2$; e.g., Piovano et al. 2020; Balazs 1983), Pacific NW $($ mean $=52.5 \%$; SE $=9.4 ; n=4)$, Indian SE (mean $=51.7 \%$; $\mathrm{SE}=14.2 ; n=5$; e.g., Shimada et al. 2014; Fukuoka et al. 2016), Pacific E (mean $=49.4 \%$; $\mathrm{SE}=7.7$; $n=18$; e.g. Seminoff et al. 2002; Arthur and Balazs 2008; Carrión-Cortez et al. 2010; Quiñones et al. 2010), and Atlantic NW (mean $=34.1 \%, \mathrm{SE}=7.7 ; n=19)$ especially high in temperate areas (e.g., Holloway-Adkins and Hansiak 2017).

Seagrass and Macroalgae. Nearly equal proportions of both seagrass and macroalgae have been recorded in diets in the following sub-regions: Pacific E (López-Mendilaharsu et al. 2005), Atlantic NW in the Gulf of Mexico (Howell et al. 2016), Indian SE at Cocos (Keeling) islands (Whiting et al. 2014), and Pacific SW at Torres Strait (Andre et al. 2005).

Terrestrial plants. Terrestrial plant contribution is highest in the following sub-regions: Atlantic SW (mean $=8.3 \%$; $\mathrm{SE}=4.7 ; n=9$ ) especially at estuarine sites, e.g., from $10 \%$ in Argentina (González Carman et al. 2014) to 35\% in Brazil (Nagaoka et al. 2012); Pacific E (mean $=3.7 \%$; $\mathrm{SE}=2.3$; $n=18$ ) especially at estuarine sites (e.g., $38 \%$ in Colombia, Sampson et al. 2018), and where mangrove fruits and leaves featured (e.g., 5\% in the Galapagos Islands, CarriónCortez et al. 2010; 3.2\% in Mexico, López-Mendilaharsu et al. 2005); and Pacific SW (mean $=3.5 \%$; $\mathrm{SE}=3.0 ; n=13$ ) where mangrove cotyledons, leaves and fruit formed $40 \%$ of the diet in Shoalwater Bay, Queensland Australia (Limpus and Limpus 2000).

Animal matter. Animal matter featured to some degree in all sub-regions, especially the following: Pacific S Central pelagic sites (mean $=35 \%$; $\mathrm{SE}=35 ; n=2$; e.g., Piovano et al. 2020); Pacific E neritic sites (mean $=30.9 \%$; $\mathrm{SE}=7.2$; $n=18$; e.g., Amorocho and Reina 2007; Jiménez et al. 2017; Quiñones et al. 2010; Paredes 2015); Mediterranean neritic sites (mean $=31.9 \%$; $\mathrm{SE}=19.7 ; n=5$; e.g., Lazar et al. 2010; Karaa et al. 2012); Indian SE neritic sites (mean $=20.7 \%$; 
Fig. 2 Comparison of the relative abundance of food items in green turtle diet across the globe: seagrass, macroalgae, terrestrial plants, animal matter and anthropogenic debris. The diet item percentages were collated from 89 datasets at 75 sites across 13 sub-regions for sea turtles (see Online Resource Table S1 for study site, analytical method, diet group results, source literature). Bold horizontal lines indicate mean, boxes delineate the upper and lower quartiles and whiskers define the data's range. Outliers are plotted as separate points
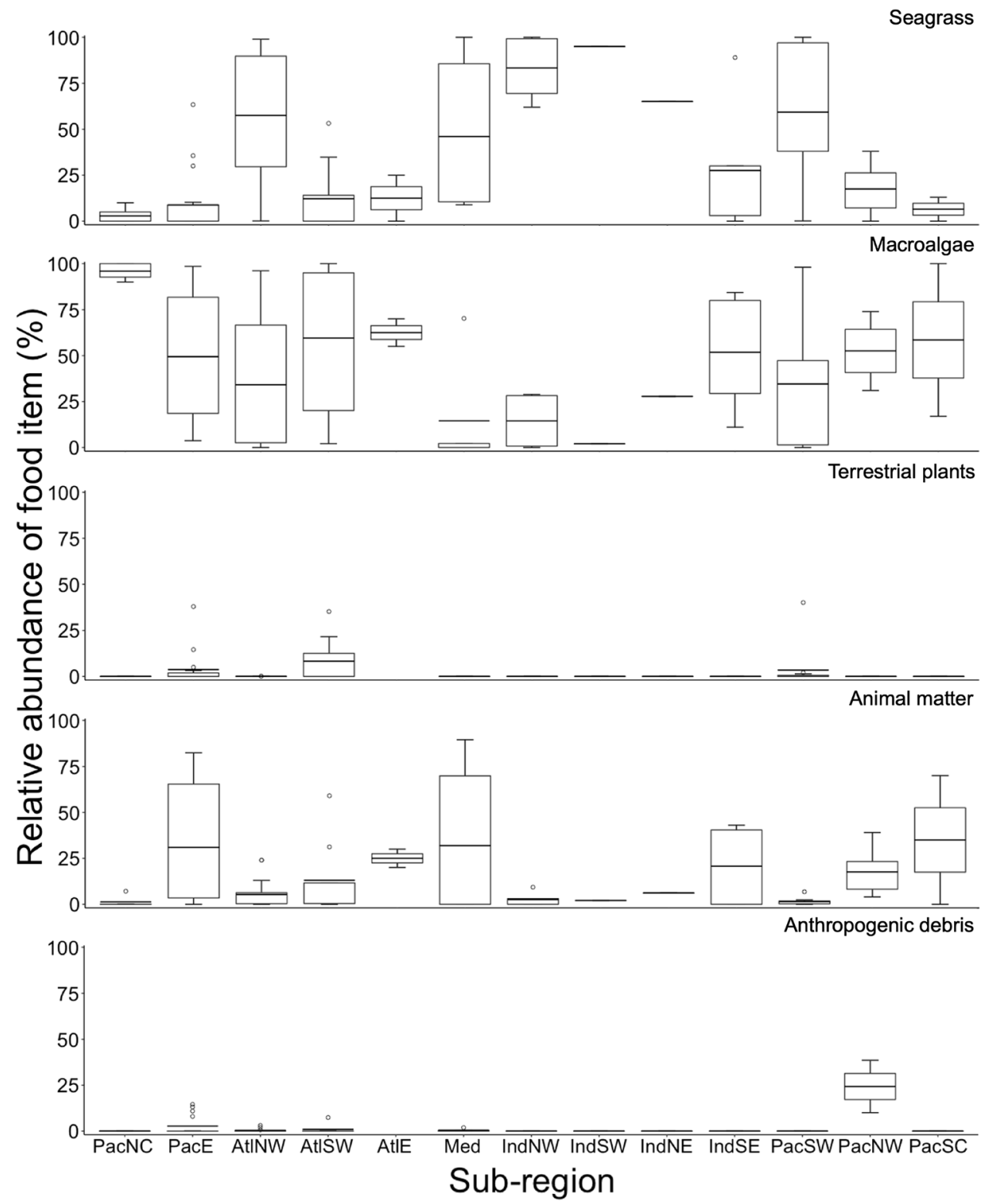

$\mathrm{SE}=9.3 ; n=5$; e.g., Burkholder et al. 2011; Thomson et al. 2018); and at Atlantic E upwelling sites (mean $=25 \%$; $\mathrm{SE}=5 ; n=2$; e.g., Hancock et al. 2018).

A comparison of the proportion of seagrass consumed by green turtles between sub-regions showed significant and major differences (Kruskal-Wallis test, $H_{12}=45.17$, $p<0.001)$. Multiple comparisons showed a significant difference between green turtle diet recorded in the Atlantic NW and Atlantic SW $(p=0.02)$, Atlantic SW and Indian NW $(p=0.03)$, Atlantic NW and Pacific E $(p=0.002)$, Indian NW and Pacific E $(p=0.008)$, Atlantic NW and Pacific $\mathrm{N}$ Central $(p=0.01)$, Indian NW and Pacific N Central $(p=0.01)$, Atlantic SW and Pacific SW $(p=0.02)$, Pacific E and Pacific SW ( $p=0.002)$, Pacific N Central and Pacific SW $(p=0.01)$. The amount of anthropogenic materials present varied amongst sites but was most abundant in the Pacific Ocean (Pacific E and Pacific NW) (Fig. 1; Fig. 2; Online Resource 1 Table S1).

\section{Relationship between green turtle diet and SST}

\section{Global SST overview}

A global comparison of principal diet components (plantdominated diet vs omnivorous diet) with seasonal SST provides an indication of the relative importance of SST on diet at different sites (Fig. 3). Our findings suggest that at cooler sites where SST is $<20^{\circ} \mathrm{C}$ for $\geq 6$ months each year, animal matter in the diet is always $>20 \%$ (range $=20.3-89.5 \%$; mean $=51.48 \pm 4.84 \% ; n=14$ sites; $n=20$ datasets). These 


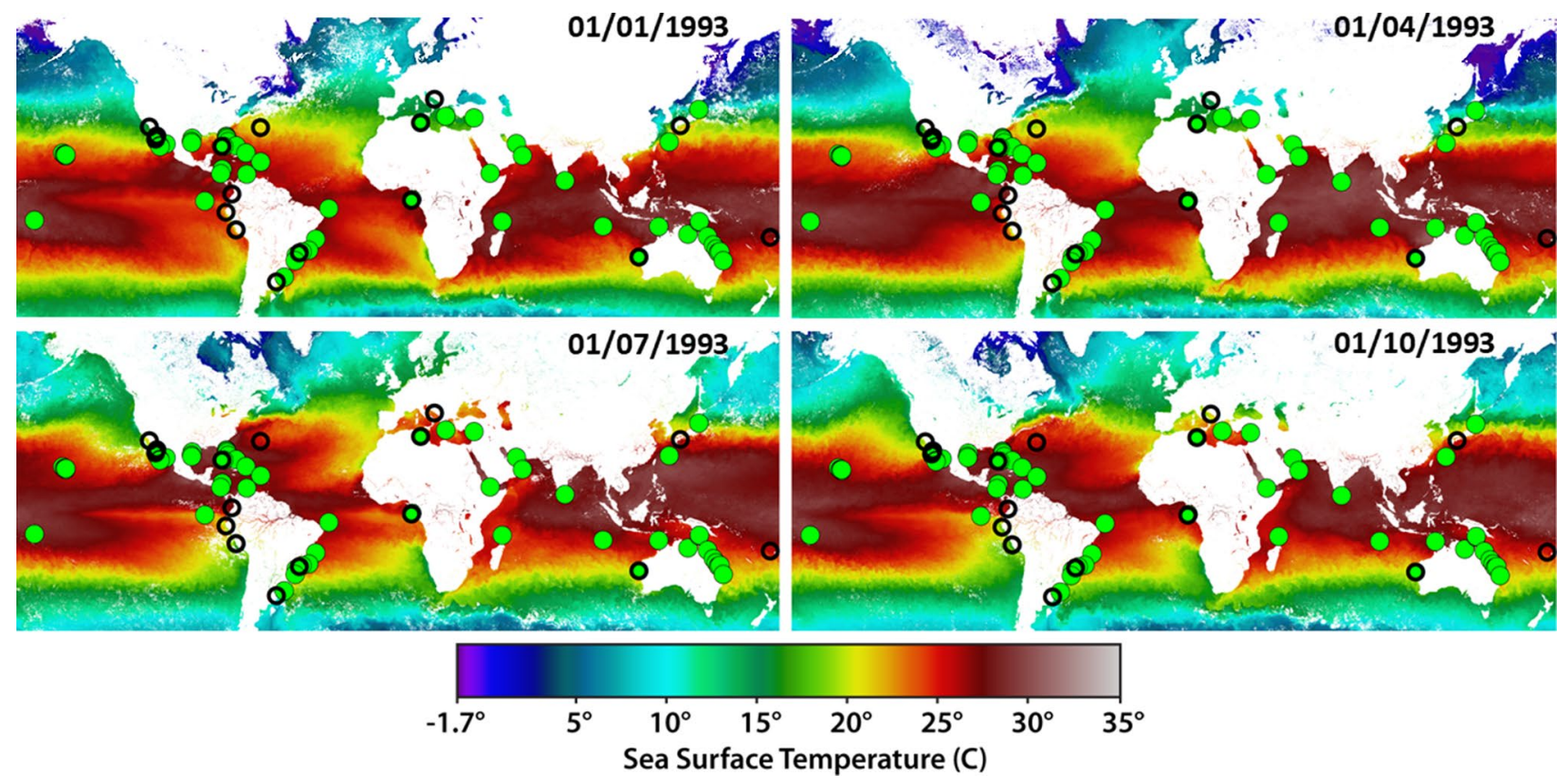

Fig. 3 The importance of plant or animal content in green turtle diet is related to sea surface temperature (SST). Generally, at higher latitudes and in cold-water currents where SST is $<20^{\circ} \mathrm{C}$ for at least two seasons, animal matter in the diet is $>20 \%$ (black circles; mean $=51.47 \%$; $\mathrm{SE}=4.84 ; n=14$ sites); whereas at warmer sites where SST $>25{ }^{\circ} \mathrm{C}$ for at least two seasons, green turtle diet is dominated by seagrass, macroalgae and mangroves (green circles; mean $=92.97 \%$; $\mathrm{SE}=9.85 ; n=57$ sites). Both plant and animal mat ter are important components at a small number of sites (green circles outlined by black, $n=4$ sites). SST temperatures from the year 1993 are at the midpoint of the study time series (1971-2016; Online Resource Table S1). SST (AVHRR) data source: Phillips et al. 2012
Fig. 4 Sea surface temperature (SST) has a small effect on green turtle diet at foraging grounds: a lower proportion of animal matter is present in the diet of turtles at sites with higher SST $\left(r^{2}=0.16, t=-3.7\right.$, $\left.F_{1,72}=13.32, P=<0.001\right)$. SST is shown as maximum annual temperature recorded during the sampling year(s) of 82 datasets from 72 sites in the Atlantic, Indian and Pacific Oceans and Mediterranean Sea. SST (ICOADS) data source: NCAR 2015

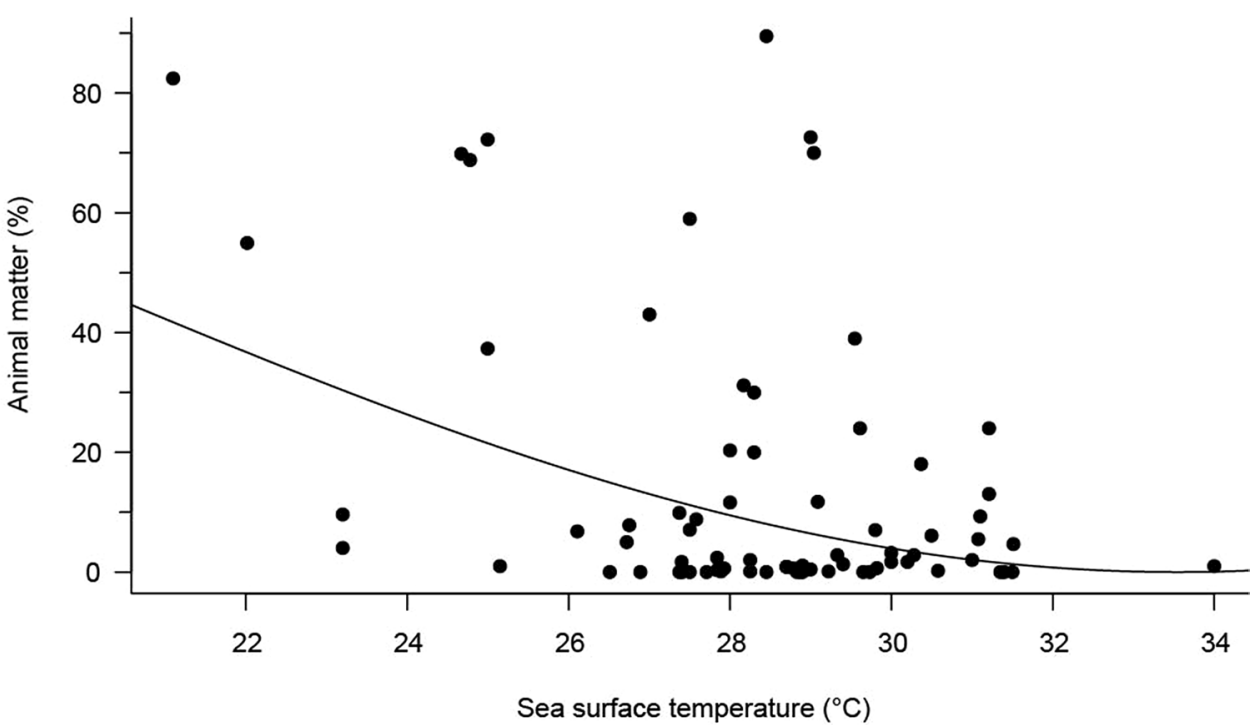

areas are at higher latitudes (e.g., California USA, Argentina and Croatia), close to cold-water currents or upwellings (e.g., Colombia and Peru) or in areas of overlapping climate zones (e.g., Brazil). Generally, at warmer sites where SST $\geq 25{ }^{\circ} \mathrm{C}$ for $9-12$ months, green turtle diet is almost always $\leq 20 \%$ animal matter and is dominated by plant matter $($ mean $=92.97 \pm 1.19 \%$; range $=45.5-100 \% ; n=57$ sites; $n=69$ datasets).

A few sites around the world are exceptions to the trend of decreasing animal matter with increasing SST. Contradicting diet preference (see Online Resource Table S1) existed at four sites, each in a different sub-region (Atlantic NW, Atlantic E, Mediterranean and Indian SE). These four sites 
(i.e., Dry Tortugas Florida USA, São Tomé Island, Gulf of Gabes Tunisia, and Shark Bay Western Australia) are represented by green circles with a black outline (the green circle indicates a plant-dominated diet and black outline indicates $>20 \%$ animal matter) (Fig. 3). Among sites with high SST and expected plant-dominated diet, one notable exception, indicated by a black ring, is Fiji (Pacific S Central) where diet is dominated by $71 \%$ animal matter (Piovano et al. 2020). Two exceptions to an expected omnivorous diet at sites with low SST values are the Sanriku coast of Japan (Pacific NW) and Galapagos Ecuador (Pacific E), both indicated by green circles (Fig. 3).

\section{Foraging site SST}

Analysis of fine-scale SST data from 72 foraging sites shows a similar pattern to that provided by the global SST overview, with a small but significant $(p=<0.001)$ relationship between SST and the proportion of animal matter in the diet ( $n=82$ datasets). The contribution of animal matter in the diet tended to increase at cooler temperatures (Fig. 4; Online Resource 1 Fig. S5) and the resulting relationship between the percent animal matter and maximum SST was small but significant $\left(r^{2}=0.16, t=-3.7, F_{1,72}=13.32, p=<0.001\right)$. Conversely, the contribution of seagrass to the diet tended to increase with warmer temperatures (Online Resource 1 Fig. S5). Maximum sea surface temperatures had a small but significant relationship to percent seagrass in the diet $\left(r^{2}=0.22, t=4.5, F_{1,72}=20.6, p=<0.001\right)$. We also found a small effect of mean SST on percent animal matter and seagrass in the diet, and a small effect of minimum SST on percent seagrass in the diet $(p<0.05$ in all cases; see Online Resource 1 Fig. S5). There was no effect of SST on contribution of either macroalgae or terrestrial plants (notably mangrove) to the diet (Online Resource 1 Fig. S5).

\section{Discussion}

Considerable variability in green turtle diet exists around the world, across oceans and within foraging grounds. Our review has captured much of the literature to tease apart spatial variation in green turtle diet and our analysis shows SST to be a driver of omnivory. At most foraging sites included in this study, as expected, green turtles were primarily herbivorous with three categories of plant material featuring in the diet: seagrass predominating at sites where it was abundant; macroalgae where seagrass is relatively sparse or absent; and terrestrial plant material (especially mangrove leaves and propagules, but also other terrestrial species) particularly in estuarine areas. Omnivory also featured at some sites.

Green turtle foraging strategies range from nearly total herbivory at some neritic sites (Stokes et al. 2019) to oceanic omnivory (Turner Tomaszewicz et al. 2018), and at some sites a high degree of omnivory even after settling at neritic habitats through adulthood (Vélez-Rubio et al. 2016). Some green turtles may shuttle between neritic and oceanic environments, as in Fiji (Piovano et al. 2020). This is in contrast to the previously documented and often assumed one-way ontogenetic habitat transition (di Beneditto et al. 2017). Drivers of green turtle diet discussed in the literature include SST, characteristics of the gut biome, prey availability, size classes of turtles and impacts of anthropogenic activities.

\section{SST as a driver of variation in green turtle diet}

Our global overview and foraging site-specific analyses showed a relationship between warmer temperatures and a seagrass diet, and lower temperatures and a diet comprising large amounts of animal matter, especially macrozooplankton. We conclude that green turtle omnivory may be partly driven by water temperature, and we present the first quantitative evidence that temperature may be an important driver of diet in green turtles at a global scale, especially where the diet includes gelatinous macrozooplankton (in particular, jellyfish and salps). Gelatinous macrozooplankton featured most prominently at oceanic and extreme-latitude sites in the Pacific and Atlantic, ranging from $40 \%$ in the Pacific NW (Fukuoka et al. 2016); 30-73\% in the oceanic Pacific NC (Parker et al. 2011; Wedemeyer-Strombel et al. 2015); 38-72\% along the Pacific E coastline (Seminoff et al. 2006; Amorocho and Reina 2007; Quiñones et al. 2010; Lemons et al. 2011; Jiménez et al. 2017); and 40-59\% in the Atlantic SW (Bugoni et al. 2003; González Carman et al. 2014). A feature shared by all these sites appears to be much cooler water temperatures $\left(<20^{\circ} \mathrm{C}\right)$ during all or part of the year. Previous studies (e.g., Etnoyer et al. 2006; Cardona et al. 2010; Santos et al. 2015) have shown that green turtle omnivory levels are influenced by SST, but ours is the first study to quantify this relationship on a global scale and highlight differences in green turtle diets in different regions.

Two patterns of geographic distribution of a gelatinous macrozooplankton diet associated with cooler water temperatures are apparent. One appears to correlate with higher latitudes and cooler temperatures (e.g., Pacific E, Pacific SC, Pacific NW, southern Atlantic SW, northern Atlantic NW, and Shark Bay Australia in Indian SE). The second may be mediated by global patterns of the major warm and cold oceanic currents. Warm ocean currents tend to flow away from the equatorial region on the western side of ocean basins, and cold ocean currents flow towards the equator on the eastern side of ocean basins. It follows that cool currents may account for the patterns of high macrozooplankton consumption that appear to be associated with the California Current (off California and Baja California), the Peru Current (off Ecuador, Peru and Columbia), and the Benguela Current 
(off Mauritania). Water temperature is known to affect the abundance and distribution of food resources in the oceans (O'Connor et al. 2007). At cooler sites, where estimated levels of carnivory are typically $>20 \%$, there is high contribution of gelatinous macro-zooplankton. While latitudinal patterns of gelatinous plankton abundance are not well known, there is some evidence that their abundance may increase at higher latitudes. For example, the leatherback turtle (Dermochelys coriacea), which feeds almost exclusively on gelatinous plankton, breeds on tropical beaches but often migrates to forage at high latitudes (e.g. Fossette et al. 2014). A recent review of taxa feeding on gelatinous plankton, showed many examples of pelagic predators from higher latitudes (Hays et al. 2018), including coho salmon (Oncorhynchus kisutch), larval/juvenile sablefish (Anoplopoma fimbria) and Cassin's Auklet (Ptychoramphus aleuticus) in waters off Vancouver Island in the northern Pacific E (Mackas et al. 2007). While there was a significant relationship between SST and the percent of animal matter in the diet, there was still considerable variability in this relationship, suggesting that other factors, in addition to SST, likely also drive the diet at individual sites. Given that we found relatively few diet studies at sites with cooler temperatures $\left(10-20^{\circ} \mathrm{C}\right.$, e.g., Brazil), the role of SST may become clearer once more diet studies are conducted at such cooler sites.

Besides gelatinous plankton, there are other animalbased sources of diet that can be grazed from the benthos. For example, neritic habitats in Fiji (Pacific SC) support a green turtle diet dominated by herbivorous (e.g., sea urchin Tripneustes gratilla) and carnivorous (e.g., cone shell Conus ebreus) invertebrates as well as fish (Piovano et al. 2020). Larger turtles of post-recruitment size and sizes typical of the benthic habitat have been observed in oceanic habitats (Turner Tomaszewicz et al. 2018); and it is possible that turtles employ shifts in foraging behaviour during multiple transitions between the neritic and oceanic habitats of Fiji (Piovano et al. 2020).

Because we used SST data at a relatively course spatial scale, our study would not have identified variations or anomalies in water temperature at the level of the relatively small home ranges that foraging green turtles typically occupy (Christiansen et al. 2017). Likewise, the relationship between green turtle diet and mean SST value derived from the multi-decadal study period is unlikely to capture changes in SST values throughout that time period, nor shifts in green turtle diets on the scale reported by Bell et al. (2019). SST data at a finer spatial and temporal scale, particularly from the shallow nearshore habitats where green turtles typically forage, might shed further light on the role of SST in driving diet.

At some foraging sites, temperature does not always predict diet composition. In Japan, low SST values would predict an omnivorous diet, as it does at Shikoku, Japan, where
39\% animal matter is reported in the diet (Shimada et al. 2014). But, at an even higher latitude with cooler temperatures on the Sanriku Coast of Japan, the diet comprised only 4-9.6\% animal matter in similarly sized turtles (Fukuoka et al. 2016).

Although not the focus of our review, many other environmental effects and limits influence the distribution of food species, such as water depth, substrate type, water clarity, and abundance of other predators that feed on prey consumed by green turtles. Temperature is not always a good predictor of diet, but other variables, such as oceanographic features (Cox et al. 2018) and availability of food items, could be (e.g., Goldbogen et al. 2015). Improving our understanding of how food availability at foraging sites drives foraging behaviour remains a critical question (Hays et al. 2016).

\section{Some other drivers of variation in green turtle diet}

Our review suggests that, in addition to SST, other drivers may influence green turtle foraging strategies across and within regions. These drivers may include a combination of factors, such as gut microflora, the influence of habitat on spatial and seasonal prey availability, and the size class of turtles. Moreover, there may be synergism between drivers.

\section{Gut microflora}

The relationship between water temperature and diet composition may be driven to some extent by physiological factors. If the gut microflora that enables turtles to digest plant material does not function efficiently at lower temperatures, turtles may opt to feed on relatively more animal material (Amorocho and Reina 2007). In the literature, spatial variation in green turtle diet has often been explained by a combination of environment (e.g., food availability, different habitats) and characteristics of the gastrointestinal microbiome which are influenced by diet (Bjorndal 1997; Price et al. 2017). For example, seagrass Thalassia testudinum dominates the Caribbean benthos and is the dominant food item (e.g., Stringell et al. 2016); while in the Galapagos (Carrión-Cortez et al. 2010) and at Heron Reef Australia (Forbes 1996), the benthos is dominated by macroalgae which comprise most of the diet. Recent advances in knowledge indicate, however, that regardless of diet, the microbiome in green turtles contains the same bacterial phyla although bacterial community composition changes over time in response to diet (Ahasan et al. 2017; Campos et al. 2018; Bloodgood et al. 2020).

At Shark Bay, Australia, even though seagrass habitat dominates, green turtles primarily assimilate energy from macroalgae and gelatinous macrozooplankton. Various hypotheses were proposed by Burkholder et al. (2011) to 
explain this anomaly including: that macroalgae and gelatinous macroplankton are more palatable than the dominant Amphibolis antarctica seagrass; that an individual's diet depends on its intestinal microflora causing a preference for either seagrass or algal dominated diets; or that a high risk of predation by sharks interferes with feeding behaviour. Certainly, Shark Bay appears to be an unusual site where green turtles are highly omnivorous and individuals specialise on varying combinations of seagrasses, macroalgae and invertebrates (Thomson et al. 2018).

\section{Prey availability}

We expect food availability will ultimately influence diet composition, with sea temperature providing a proximal influence on diet through its role on prey availability. Foraging strategy (commonly described by the Optimal Foraging Theory) predicts that individuals adjust their movements according to the spatial distribution of their prey so that a more productive environment should lead to more specialised diet (MacArthur and Pianka 1966). In this way, diet composition variation and distribution has been linked to availability of food (or prey) across marine taxa, including seabirds, marine mammals and reptiles (e.g., León and Bjorndal 2002; Pinaud et al. 2005; Hays et al. 2006; Womble and Sigler 2006).

A recent review of intraspecific variation in trophic ecology of sea turtles using SIA confirms the versatility in trophic ecology that has been suggested for green turtles (Figgener et al. 2019), emphasising the cryptic and contrasting nature of diets in adult green turtle populations. Variations in upwelling processes in the Galapagos Islands (Pacific E), affect algal composition leading to higher diversity of red algae in diet at some sites (Carrión-Cortez et al. 2010). In Hawaii (Pacific NC), differences in the relative availability of seagrass and macroalgae are apparent over short distances. For example, green turtles consumed both seagrass and macroalgae at Kāne'ohe Bay, O'ahu but only macroalgae at other sites amongst the six main islands of Hawaii (Arthur and Balazs 2008). At São Tomé island (Atlantic E), at two foraging sites (separated by $50 \mathrm{~km}$ ), diet composition indicated distinct isotopic niches: a diet dominated by macroalgae and animal matter at one rocky reef site (with no seagrass) and a mixed diet of seagrass, macroalgae and animal matter at a site with seagrass (Hancock et al. 2018). Besides availability of diet components, it is also important to consider their energy value via nutritional composition (e.g., protein, fat content, Neutral Detergent Fibre (NDF) that affects digestibility). Nutrition analysis for diet of green turtles has been conducted at a number of sites (e.g. Bjorndal 1979; Sampson et al. 2018) but nutritional values are not available for many dietary components (e.g.,
Thalassodendron ciliatum Trevathan-Tackett et al. 2017), and this is an important area for future research.

We were unable to properly analyse the relationship between food availability and diet composition due to lack of detailed data about both sets of variables in individual studies. Nevertheless, all studies that recorded no seagrass in the diet, such as those in the Atlantic SW (Reisser et al. 2013; Darré Castell et al. 2005) and in the southern Pacific E (Carrión-Cortez et al. 2010; Jiménez et al. 2017), were from regions characterised by sparse to non-existent seagrass habitats (UNEP-WCMC \& Short 2018). The global distribution layer for seagrass based on point data (UNEP-WCMC \& Short 2018) is currently the most accurate dataset available, and although a recent study has estimated seagrass extent worldwide, the authors describe numerous weaknesses in the data (McKenzie et al. 2020) limiting its utility as a quantitative data source. This means the dataset offers no metrics with which to estimate seagrass availability as a driver of amount of seagrass in green turtle diet at a local level.

\section{Size class of turtles}

Size class may be expected to play a role in determining rates of omnivory. Studies across taxa demonstrate that individuals maximise growth rates from juvenile to maturity by selecting a high protein diet. This has been demonstrated for a variety of reptiles (e.g., Durtsche 2004; Bouchard and Bjorndal 2006; Wotherspoon and Burgin 2016) which may explain why animal matter is so important for post-hatching green turtles $<25 \mathrm{~cm}$ CCL (Hancock et al. 2018).

The timing and the size class at which the dietary shift between late pelagic stage and neritic recruitment varies across sub-regions. For example, green turtles in the Atlantic (Bjorndal and Bolten 1988) shift to a neritic life stage at a smaller size than those in the Indo-Pacific (Limpus et al. 1994). Stable isotope studies that sample inert tissues (e.g. bone growth layers) enable assessment of foraging history and determination of the timing of ontogenetic shift, e.g., at 20-25 cm CCL in the Atlantic SW (Bjorndal et al. 2000). This method has been used to show that timing varies across sub-regions in Atlantic SW, Pacific SW, and Mediterranean (see Reich et al. 2007; Arthur et al 2008; Cardona et al. 2010; González Carman et al. 2012; Howell et al. 2016). In Uruguay (Atlantic SW), turtles shift from omnivory (gelatinous microzooplankton) to herbivory at approximately $45 \mathrm{~cm}$ CCL (Vélez-Rubio et al. 2016), but along the NW coast of Africa (Atlantic E) at about $59 \mathrm{~cm}$ CCL (Cardona et al. 2009). No clear ontogenetic dietary shift was reported at foraging sites in either the western Pacific, Pacific E, or Atlantic E as levels of omnivory were similar for both juveniles $>25 \mathrm{~cm} \mathrm{CCL}$ and adults (Lemons et al. 2011; Shimada et al. 2014; Hancock et al. 2018). 
Nevertheless, intra-population variation in diet composition also exists (Burgett et al. 2018).

Animal matter decreased in importance for larger size classes in the Gulf of Gabes (Mediterranean) (Karaa et al. 2012) and in the Dry Tortugas National Park, Florida (Atlantic NW) (Roche, 2016). At a few sites, larger size classes foraging in tropical seagrass meadows may exhibit high levels of omnivory. For example, at Fiji (Pacific SC), the diet of turtles measuring $43-89 \mathrm{~cm}$ CCL was $71 \%$ animal matter (40\% invertebrates and $31 \%$ fishes) (Piovano et al. 2020).

Unfortunately, because many diet studies included in this review did not differentiate between size classes, we were unable to further explore size class as a driver of omnivory. We encourage future diet studies to incorporate size class into their analyses, as it may help clarify timing of the ontogenetic shift from a pelagic to a benthic life stage.

\section{Anthropogenic impacts}

Our review found that the highest levels of anthropogenic debris in the diets of green turtles were in the Pacific Ocean. In the Pacific E, at Sechura Bay, Peru (Jiménez et al. 2017) and in Gorgona Park, Colombia (Sampson et al. 2018), 8\% and $13.1 \%$ of diet, respectively, comprised anthropogenic debris. In the Pacific NW, green turtles foraging along the Sanriku coast of Japan ingested a range of artificial debris, including hard and soft plastics, styrofoam, fishing line/rope and rubber (Fukuoka et al. 2016). Coastal habitat degradation associated with anthropogenic development, such as that at highly urbanised sites along the east coast of Brazil in the Atlantic SW, affects the diversity of food items and can contribute to low dietary diversity in green turtles (Santos et al. 2011). Furthermore, Santos et al. (2015) report high foraging plasticity amongst green turtles in estuaries that combine an estuarine diet with pelagic foraging, perhaps in response to habitat degradation.

\section{Relative merits and constraints of diet analysis techniques}

Our review describes diet composition based on studies that used a variety of analytical methods, each characterised by benefits and disadvantages. Besides less-invasive direct observation of foraging behaviour (e.g., Schofield et al. 2006), two relatively simple and low-cost traditional quantitative methods of gut content analysis provide specific information on the composition, occurrence and quantity of species consumed (Miller et al. 2010). The analysis of a dissected gut provides an unbiased record (Gama et al. 2016) of recently ingested food from the oesophagus (e.g., Stokes et al. 2019). Oesophageal lavage from live animals is more common but only provides an indicative record of food consumed due to relatively small sample sizes produced and selective retention of larger items by oesophageal papillae (Reisser et al. 2013). SIA has developed in the past two decades as a powerful tool to complement these traditional methods of studying diet and trophic ecology (see review by Haywood et al. 2019). Analysis of the composition of stable isotopes $\left(\delta^{13} \mathrm{C}\right.$ and $\left.\delta^{15} \mathrm{~N}\right)$ in tissues with different residence times provides historical evidence of diet and patterns of ontogenetic shift (Arthur et al. 2008; Cardona et al. 2009; Vander Zanden et al. 2013; Vélez-Rubio et al. 2018). For example, blood serum represents food consumed recently and epidermal tissue or scutes represent the diet consumed several months previously (Reich et al. 2008). In some cases, however, SIA may over-estimate the relative volume of animal matter in the diet because a higher proportion of animalsourced $\delta^{15} \mathrm{~N}$ may be assimilated into the tissues compared with plant-sourced $\delta^{15} \mathrm{~N}$; or it may misrepresent relative contributions of different types of plant matter (Lemons et al. 2011; Bezerra et al. 2015). Remote videography can provide insights to diet composition; however, it is difficult to calculate the relative contribution to diet from video observations of bite counts without support from other techniques (Thomson et al. 2018).

The results of diet studies can be biased by the type of sampling used. Broadly, gut contents represent ingestion and SIA values measure assimilation. Bite counts/events from video footage may not provide an accurate measure of amounts ingested. Animal matter may be overestimated by SIA and video analysis. At Bahia de los Angeles, Mexico, depending on sampling technique, animal matter was found to comprise 3\% (oesophageal lavage), 20\% (gut content) and $32 \%$ (video) (Seminoff et al. 2002; 2006). Similarly, at Shark Bay, Australia, animal matter was measured at 0\% (oesophageal lavage), 20\% (SIA), and 40-43\% (video) (Burkholder et al. 2011; Thomson et al. 2018). It would be interesting to conduct simultaneous studies using multiple methods at other sites to confirm whether such relative differences are consistent.

In contrast to traditional gut sampling, SIA analyses have teased apart some of the cryptic components of green turtle diet. In the Caribbean, Vander Zanden et al. (2013) reported that while green turtles in Costa Rica might appear to have a more omnivorous diet (due to presence of higher $\delta 15$ values) than foraging aggregations in neighbouring Nicaragua, in fact, differences in stable isotope composition were attributable to regional variation in primary production and nutrient cycling rather than differences in patterns of prey consumption (Vander Zanden et al. 2013). Another limitation of SIA is that all prey items must be sampled within the same time frame that the sampled tissues are synthesised (Haywood et al. 2019). It follows that stable isotope studies that only sample potential prey items previously identified in gut or lavage samples taken at a foraging site risk excluding important prey items. For example, in Bermuda, samples 
of seagrass, macroalgae and certain potential prey animals were analysed to determine stable isotope ratios (Burgett et al. 2018). But, because the diet studies had not identified mangroves in their lavage samples, stable isotopes of mangroves were not assessed even though it is possible that mangroves which occurred in the area actually featured in the diet. Sampson et al. (2018) reported they were unable to run the MixSIAR model for green turtles due to exclusion of key prey items that were not considered potential prey from previous lavage studies.

\section{Climate change considerations}

Our study concludes that SST has a small but significant effect on levels of omnivory, and so a warming climate is likely to modify the prey available to green turtles. There is some evidence that recent changes in forage availability are associated with changes in water temperature, particularly in shallow waters where summertime superheating can lead to major loss of temperature-sensitive seagrasses (Campbell et al. 2006). For example, a major die-off of colder-water seagrass species occurred in response to a marine heatwave that impacted the important green turtle foraging area in Shark Bay, Western Australia (Arias-Ortiz et al. 2018).

Future changes in local conditions (e.g. SST, sea level, salinity or water current regime) may modify ecosystem structure and biodiversity (Thomson and Heithaus 2014). An overall reduction in seagrass habitat globally has been predicted during the next decade due to a combination of anthropogenic threats (Unsworth et al. 2019). Climate change might alter patterns of oceanic currents, gyres and eddies (Toggweiler and Russell 2008) and thereby affect water temperature and the availability and distribution of sea turtle food resources. Moreover, habitats are rarely static through time and can undergo long-term natural cycles of loss and recovery (Rasheed and Unsworth 2011) influencing their capacity to support grazing turtles.

Our review indicates that green turtle diets are variable, and this flexibility may enable adaptation to changing resources after environmental perturbations, such as marine heatwaves (Arias-Ortiz et al. 2018). Turtles may adapt to seasonal changes in food availability by modifying their diets (González Carman et al. 2012). Green turtles can alter their foraging behaviour as evidenced by consumption of invasive seagrass species that spread into key foraging habitats (e.g., Becking et al. 2014; Whitman et al. 2019). Turtles might also expand their foraging home ranges, as they have with serial residency in Shark Bay, Western Australia (Thomson et al. 2018), or they may shuttle between foraging sites (Piovano et al. 2019) or even adapt to new foraging sites, as demonstrated by a loggerhead turtle that re-located to a new site after flooding and a tropical cyclone destroyed $>1000 \mathrm{~km}^{2}$ benthic habitat in its home range (Shimada et al. 2020).

Flexibility in green turtle diet is evident across regions. Temporary diet switching between seagrass and macroalgae has been recorded by individual green turtles (Fuentes et al. 2006) and longer-term diet shifts in response to invasive algae have been observed in turtle aggregations (Russell and Balazs 2015; Christianen et al. 2019). Likewise, green turtles have adapted their diet to changing environments through seasonal variation in diet (Piovano et al. 2020) and switching between reef and estuarine habitats (MachovskyCapuska et al. 2020). At the extremes of their geographic distribution, the foraging plasticity of green turtles is demonstrated by an omnivorous diet and pelagic foraging (Santos et al. 2015). Green turtles are highly adaptive, but whether turtles will be able to sufficiently shift their diet in response to warming SST remains a concern for this threatened species. In conclusion, ours is the first study to document the full extent of variation in green turtle diet in different regions throughout the world, and to quantify this relationship on a global scale. We were also able to demonstrate a correlation between water temperature and diet composition, which has important implications in the face of climate change.

Acknowledgements This work was supported by the Bertarelli Foundation as part of the Bertarelli Programme in Marine Science. HJS was supported with a PhD studentship from the Bertarelli Foundation and Swansea University. We would like to thank Winter Dotto for assistance with Spanish and Portuguese translations. We thank Dr Jeffrey Seminoff, Dr Alexander Gaos and three anonymous reviewers for their constructive suggestions to improve the manuscript.

Author contributions NE, JAM and GCH conceived the study. HJS, JAM and NE conducted the diet literature review, NE carried out the SST global analysis. JOL collated and analysed the SST dataset. NE, JAM and GCH led the writing of the manuscript with contributions from all authors.

Funding This work was supported by the Bertarelli Foundation as part of the Bertarelli Programme in Marine Science. HJS was supported with $\mathrm{PhD}$ studentship from the Bertarelli Foundation and Swansea University.

Data availability All diet data are presented in Online Resource 1 (Tables S1 and S2). Online data are acknowledged at appropriate points of the Methods and Reference sections.

\section{Compliance with ethical standards}

Conflicts of interest No conflicts of interest or competing interests to declare.

Code availability (software application or custom code) Not applicable.

Open Access This article is licensed under a Creative Commons Attribution 4.0 International License, which permits use, sharing, adaptation, distribution and reproduction in any medium or format, as long as you give appropriate credit to the original author(s) and the source, 
provide a link to the Creative Commons licence, and indicate if changes were made. The images or other third party material in this article are included in the article's Creative Commons licence, unless indicated otherwise in a credit line to the material. If material is not included in the article's Creative Commons licence and your intended use is not permitted by statutory regulation or exceeds the permitted use, you will need to obtain permission directly from the copyright holder. To view a copy of this licence, visit http://creativecommons.org/licenses/by/4.0/.

\section{References}

Ahasan MS, Waltzek TB, Huerlimann R, Ariel E (2017) Faecal bacterial communities of wild-captured and stranded green turtles (Chelonia mydas) on the Great Barrier Reef. FEMS Microbiol Ecol. 93:fix139. https://doi.org/10.1093/femsec/fix139

Amorocho DF, Reina RD (2007) Feeding ecology of the East Pacific green sea turtle Chelonia mydas agassizii at Gorgona National Park, Colombia. Endanger Specs Res 3:43-51. https://doi. org/10.3354/esr003043

Andre J, Gyuris E, Lawler IR (2005) Comparison of the diets of sympatric dugongs and green turtles on the Orman Reefs, Torres Strait, Australia. Wildl Res 32:53-62. https://doi.org/10.1071/ WR04015

Arias-Ortiz A, Serrano O, Masqué P, Lavery PS, Mueller U, Kendrick GA, Rozaimi M, Esteban A, Fourqurean JW, Marbà N, Mateo MA, Murray K, Rule M, Duarte CM (2018) A marine heatwave drives massive losses from the world's largest seagrass carbon stocks. Nat Clim Change 8:338. https://doi.org/10.1038/s4155 8-018-0096-y

Arthur KE, Balazs GH (2008) A comparison of immature Green Turtle (Chelonia mydas) diets among seven sites in the Main Hawaiian Islands. Pac Sci 2:205-217. https://doi.org/10.2984/15346188(2008)62[205:ACOIGT]2.0.CO;2

Arthur KE, Limpus CJ, Roelfsema CM, Udy JW, Shaw GR (2006) A bloom of Lyngbya majuscula in Shoalwater Bay, Queensland, Australia: an important feeding ground for the green turtle (Chelonia mydas). Harmful Algae 5:251-265. https://doi. org/10.1016/j.hal.2005.07.006

Arthur KE, Boyle MC, Limpus CJ (2008) Ontogenetic changes in diet and habitat use in green sea turtle (Chelonia mydas) life history. Mar Ecol Prog Ser 362:303-311. https://doi.org/10.3354/meps0 7440

Arthur KE, McMahon KM, Limpus CJ, Dennison WC (2009) Feeding ecology of green turtles (Chelonia mydas) from Shoalwater Bay, Australia. Mar Turtle Newsl 123:6-12

Balazs GH (1983) Sea turtles and their traditional usage in Tokelau. Atoll Res. Bull. 279. doi: 10.5479/si.00775630.279.1

Balazs GH, Forsyth RG, Kam AK (1987) Preliminary assessment of habitat utilization by Hawaiian green turtles in their resident foraging pastures. NOAA Tech Memo NMFS, NOAA-TM-NMFS-SWFC-71.

Becking LE, Bussel TCV, Debrot AO, Christianen MJ (2014) First record of a Caribbean green turtle (Chelonia mydas) grazing on invasive seagrass (Halophila stipulacea). Caribb J Sci 48:162163. https://doi.org/10.18475/cjos.v48i3.a05

Bell IP, Meager J, van de Merwe JP, Hof CAM (2019) Green turtle (Chelonia mydas) population demographics at three chemically distinct foraging areas in the northern Great Barrier Reef. Sci Total Environ 652:1040-1050. https://doi.org/10.1016/j.scito tenv.2018.10.150

Bezerra MF, Lacerda LD, Rezende CE, Franco MAL, Almeida MG, Macêdo GR, Pires TT, Rostán G, Lopez GG (2015) Food preferences and $\mathrm{Hg}$ distribution in Chelonia mydas assessed by stable isotopes. Environ Pollut 206:236-246. https://doi.org/10.1016/j. envpol.2015.07.011

Bjorndal KA (1979) Cellulose digestion and volatile fatty acid production in the green turtle, Chelonia mydas. Comp Biochem Physiol 63A:127-133

Bjorndal KA (1980) Nutrition and grazing behavior of the green turtle Chelonia mydas. Mar Biol 56:147-154. https://doi.org/10.1007/ BF00397131

Bjorndal KA (1997) Foraging ecology and nutrition of sea turtles. In: Lutz PL, Musick JA (eds) The Biology of Sea Turtles, Vol I. CRC Press, Boca Raton, FL, p 199-232

Bjorndal KA, Bolten AB (1988) Growth rates of immature green turtles, Chelonia mydas, on feeding grounds in the southern Bahamas. Copeia 3:555-564. https://doi.org/10.2307/1445373

Bjorndal KA, Bolten AB, Chaloupka MY (2000) Green turtle somatic growth model: evidence for density dependence. Ecol Appl 10:269-282. https://doi.org/10.1890/10510761(2000)010[0269:GTSGME]2.0.CO;2

Bloodgood JC, Hernandez SM, Isaiah A, Suchodolski JS, Hoopes LA, Thompson PM, Waltzek TB, Norton TM (2020) The effect of diet on the gastrointestinal microbiome of juvenile rehabilitating green turtles (Chelonia mydas). PLoS One 15(1):e0227060. https://doi.org/10.1371/journal.pone.0227060

Bouchard SS, Bjorndal KA (2006) Ontogenetic diet shifts and digestive constraints in the omnivorous freshwater turtle Trachemys scripta. Physiol Biochem Zool 79:150-158. https://doi. org/10.1086/498190

Boyle MC, Limpus CJ (2008) The stomach contents of post-hatchling green and loggerhead sea turtles in the southwest Pacific: an insight into habitat association. Mar Biol 155:233-241. https://doi.org/10.1007/s00227-008-1022-z

Brewin R, Smale D, Moore P, Dall'Olmo G, Miller P, Taylor B, Smyth T, Fishwick J, Yang M (2018) Evaluating operational AVHRR sea surface temperature data at the coastline using benthic temperature loggers. Remote Sens 10:925. https://doi. org/10.3390/rs 10060925

Broderick A, Patricio A (2019) Chelonia mydas South Atlantic subpopulation. The IUCN Red List of Threatened Species 2019: e.T142121866A142086337. http://dx.doi.org/10.2305/IUCN. UK.2019-2.RLTS.T142121866A142086337.en. Downloaded on 15 May 2020.

Brodeur RD, Smith BE, McBride RS, Heintz R, Farley E (2017) New perspectives on the feeding ecology and trophic dynamics of fishes. Environ Biol Fishes 100:293-297. https://doi. org/10.1007/s10641-017-0594-1

Bugoni L, Krause L, Petry MV (2003) Diet of sea turtles in Southern Brazil. Chelonian Conserv Biol 4:685-688

Burgett CM, Burkholder DA, Coates KA, Fourqurean VL, Kenworthy WJ, Manuel SA, Outerbridge ME, Fourqurean JW (2018) Ontogenetic diet shifts of green sea turtles (Chelonia mydas) in a mid-ocean developmental habitat. Mar Biol 165:33. https ://doi.org/10.1007/s00227-018-3290-6

Burkholder DA, Heithaus MR, Thomson JA, Fourqurean JW (2011) Diversity in trophic interactions of green sea turtles Chelonia mydas on a relatively pristine coastal foraging ground. Mar Ecol Prog Ser 439:277-293. https://doi.org/10.3354/meps0 9313

Campbell SJ, McKenzie LJ, Kerville SP (2006) Photosynthetic responses of seven tropical seagrasses to elevated seawater temperature. J Exp Mar Biol Ecol 330:455-468. https://doi. org/10.1016/j.jembe.2005.09.017

Campos P, Guivernau M, Prenafeta-Boldu' FX, Cardona L, (2018) Fast acquisition of a polysaccharide fermenting gut microbiome by juvenile green turtles Chelonia mydas after settlement in coastal habitats. Microbiome 6:69. https://doi.org/10.1186/ s40168-018-0454-z 
Cardona L, Aguilar A, Pazos L (2009) Delayed ontogenic dietary shift and high levels of omnivory in green turtles (Chelonia mydas) from the NW coast of Africa. Mar Biol 156:1487-1495. https:// doi.org/10.1007/s00227-009-1188-Z

Cardona L, Campos P, Levy Y, Demetropoulos A, Margaritoulis D (2010) Asynchrony between dietary and nutritional shifts during the ontogeny of green turtles (Chelonia mydas) in the Mediterranean. J Exp Mar Biol Ecol 393:83-89. https://doi.org/10.1016/j. jembe.2010.07.004

Carrión-Cortez JA, Zárate P, Seminoff JA (2010) Feeding ecology of the green sea turtle (Chelonia mydas) in the Galapagos Islands. J Mar Biol Assoc UK 90:1005-1013. https://doi.org/10.1017/ s0025315410000226

Chaloupka M, Bjorndal KA, Balazs GH, Bolten AB, Ehrhart LM, Limpus CJ, Suganuma H, Troëng S, Yamaguchi M (2008) Encouraging outlook for recovery of a once severely exploited marine megaherbivore. Global Ecol \& Biogeog 17:297-304. https://doi.org/10.1111/j.1466-8238.2007.00367.x

Christianen MJ, Smulders FO, Engel MS, Nava MI, Willis S, Debrot AO, Palsbøll PJ, Vonk JA, Becking LE (2019) Megaherbivores may impact expansion of invasive seagrass in the Caribbean. Ecol 107:45-57. https://doi.org/10.1111/1365-2745.13021

Christiansen F, Esteban N, Mortimer JA, Dujon AM, Hays GC (2017) Diel and seasonal patterns in activity and home range size of green turtles on their foraging grounds revealed by extended Fastloc-GPS tracking. Mar Biol 164:10. https://doi. org/10.1007/s00227-016-3048-y

Cox S, Embling CB, Hosegood PJ, Votier SC, Ingram SN (2018) Oceanographic drivers of marine mammal and seabird habitat-use across shelf-seas: a guide to key features and recommendations for future research and conservation management. Estuar Coast Shelf S 212:294-310. https://doi.org/10.1016/j. ecss.2018.06.022

Darré Castell E, López-Mendilaharsu M, Izquierdo G (2005) Hábitos alimentarios de juveniles de tortuga verde (Chelonia mydas) en Cerro Verde, Rocha-Uruguay. II Jornada de Conservação e Pesquisa de Tartarugas Marinhas no Atlântico Sul Ocidental (Praia do Cassino, RS,14-15 de Novembro de 2005)

di Beneditto APM, Siciliano S, Monteiro LR (2017) Herbivory level and niche breadth of juvenile green turtles (Chelonia mydas) in a tropical coastal area: insights from stable isotopes. Mar Biol 164:13. https://doi.org/10.1007/s00227-016-3044-2

Dodge KL, Kukulya AL, Burke E, Baumgartner MF (2018) TurtleCam: a "smart" autonomous underwater vehicle for investigating behaviors and habitats of sea turtles. Front Mar Sci 5:90. https://doi.org/10.3389/fmars.2018.00090

Duffy JE, Cardinale BJ, France KE, McIntyre PB, Thébault E, Loreau M (2007) The functional role of biodiversity in ecosystems: incorporating trophic complexity. Ecol Lett 10:522-538. https://doi.org/10.1111/j.1461-0248.2007.01037.x

Durtsche RD (2004) Ontogenetic variation in digestion by the herbivorous lizard Ctenosaura pectinata. Physiol Biochem Zool 77:459-470. https://doi.org/10.1086/383502

Esteban N, Unsworth RKF, Gourlay JBQ, Hays GC (2018) The discovery of deep-water seagrass meadows in a pristine Indian Ocean wilderness revealed by tracking green turtles. Mar Pollut Bull 134:99-105. https://doi.org/10.1016/j.marpo lbul.2018.03.018

Etnoyer P, Canny D, Mate BR, Morgan LE, Ortega-Ortiz JG, Nichols WJ (2006) Sea-surface temperature gradients across blue whale and sea turtle foraging trajectories off the Baja California Peninsula, Mexico. Deep Sea Res Part II 53(3-4):340-358. https:// doi.org/10.1016/j.dsr2.2006.01.010

Figgener C, Bernardo J, Plotkin PT (2019) Beyond trophic morphology: stable isotopes reveal ubiquitous versatility in marine turtle trophic ecology. Biol Rev 94:1947-1973. https://doi.org/10.1111/ brv. 12543

Forbes GA (1996) The diet and feeding ecology of the green sea turtle (Chelonia mydas) in an algal-based coral reef community. $\mathrm{PhD}$ thesis, James Cook University, Queensland, Australia.

Fossette S, Witt MJ, Miller P, Nalovic MA, Albareda D, Almeida AP, Broderick AC, Chacón-Chaverri D, Coyne MS, Domingo A, Eckert S (2014) Pan-Atlantic analysis of the overlap of a highly migratory species, the leatherback turtle, with pelagic longline fisheries. Proc R Soc B 281:20133065. https://doi.org/10.1098/ rspb.2013.3065

Frazier J (1971) Observations on sea turtles at Aldabra Atoll. Philos Trans R Soc Lond B 260:373-410. https://doi.org/10.1098/rstb1 971.0019

Fuentes MMPB, Gyuris E, Lawler IR (2006) Dietary preferences of juvenile green turtles (Chelonia mydas) on a tropical reef flat. Wildl Res 33:671-678. https://doi.org/10.1071/WR05081

Fukuoka T, Yamane M, Kinoshita C, Narazaki T, Marshall GJ, Abernathy KJ, Miyazaki N, Sato K (2016) The feeding habit of sea turtles influences their reaction to artificial marine debris. Sci Rep 6:28015. https://doi.org/10.1038/srep28015

Fukuoka T, Narazaki T, Kinoshita C, Sato K (2019) Diverse foraging habits of juvenile green turtles (Chelonia mydas) in a summerrestricted foraging habitat in the northwest Pacific Ocean. Mar Biol 166:25. https://doi.org/10.1007/s00227-019-3481-9

Gama LR, Domit C, Broadhurst MK, Fuentes MM, Millar RB (2016) Green turtle Chelonia mydas foraging ecology at $25^{\circ} \mathrm{S}$ in the western Atlantic: evidence to support a feeding model driven by intrinsic and extrinsic variability. Mar Ecol Prog Ser 542:209219. https://doi.org/10.3354/meps11576

Garnett ST, Price IR, Scott FJ (1985) The diet of the green turtle, Chelonia mydas (L.), in Torres Strait. Wildl Res 12:103-112. https ://doi.org/10.1071/WR9850103

Goldbogen JA, Hazen EL, Friedlaender AS, Calambokidis J, DeRuiter SL, Stimpert AK, Southall BL (2015) Prey density and distribution drive the three-dimensional foraging strategies of the largest filter feeder. Funct Ecol 29:951-961. https://doi. org/10.1111/1365-2435.12395

González Carman V, Falabella V, Maxwell S, Albareda D, Campagna C, Mianzan H (2012) Revisiting the ontogenetic shift paradigm: the case of juvenile green turtles in the SW Atlantic. J Exp Mar Biol Ecol 429:64-72. https://doi.org/10.1016/j.jembe .2012 .06 .007

González Carman V, Marcelo Acha E, Maxwell SM, Albareda D, Campagna C, Mianzan H (2014) Young green turtles, Chelonia mydas, exposed to plastic in a frontal area of the SW Atlantic. Mar Pollut Bull 78:56-62. https://doi.org/10.1016/j.marpo lbul.2013.11.012

Hamann M, Godfrey MH, Seminoff JA, Arthur K, Barata PC, Bjorndal KA, Bolten AB, Broderick AC, Campbell LM, Carreras C, Casale P (2010) Global research priorities for sea turtles: informing management and conservation in the 21 st century. Endang Species Res 11:245-269. https://doi.org/10.3354/esr00279

Hancock JM, Vieira S, Jimenez V, Rio JC, Rebelo R (2018) Stable isotopes reveal dietary differences and site fidelity in juvenile green turtles foraging around São Tomé Island, West Central Africa. Mar Ecol Prog Ser 600:165-177. https://doi.org/10.3354/ meps 12633

Hasbún CR, Lawrence AJ, Samour JH, Al-Ghais SM (2000) Preliminary observations on the biology of green turtles, Chelonia mydas, from the United Arab Emirates. Aquatic Conserv 10:311322. https://doi.org/10.1002/1099-0755(200009/10)10:5\%3c311 ::AID-AQC414\%3e3.0.CO;2-Z

Hays GC, Hawkes LA (2018) Satellite tracking sea turtles: opportunities and challenges to address key questions. Front Mar Sci 5:432. https://doi.org/10.3389/fmars.2018.00432 
Hays GC, Hobson VJ, Metcalfe JD, Righton D, Sims DW (2006) Flexible foraging movements of leatherback turtles across the North Atlantic Ocean. Ecol 87:2647-2656. https://doi. org/10.1890/0012-9658(2006)87[2647:FFMOLT]2.0.CO;2

Hays GC, Mortimer JA, Ierodiaconou D, Esteban N (2014) Use of long-distance migration patterns of an endangered species to inform conservation planning for the world's largest Marine Protected Area. Conserv Biol 28:1636-1644. https://doi. org/10.1111/cobi.12325

Hays GC, Ferreira LC, Sequeira AM, Meekan MG, Duarte CM, Bailey H, Bailleul F, Bowen WD, Caley MJ, Costa DP, Eguíluz VM (2016) Key questions in marine megafauna movement ecology. Trends Ecol Evol 31:463-475. https://doi.org/10.1016/j. tree.2016.02.015

Hays GC, Doyle TK, Houghton JDR (2018) A paradigm shift in the trophic importance of jellyfish? Trends Ecol Evol 33:874-884. https://doi.org/10.1016/j.tree.2018.09.001

Hays GC, Cerritelli G, Esteban N, Rattray A, Luschi P (2020) Open Ocean Reorientation and Challenges of Island Finding by Sea Turtles during Long-Distance Migration. Curr Biol 30:32363242. https://doi.org/10.1016/j.cub.2020.05.086

Haywood JC, Fuller WJ, Godley BJ, Shutler JD, Widdicombe S, Broderick AC (2019) Global review and inventory: how stable isotopes are helping us understand ecology and inform conservation of marine turtles. Mar Ecol Prog Ser 613:217-245. https://doi. org/10.3354/meps12889

Heithaus MR, McLash JJ, Frid A, Dill LM, Marshall GJ (2002) Novel insights into green sea turtle behaviour using animal-borne video cameras. J Mar Biol Assoc UK 82:1049-1050. https:// doi.org/10.1017/S0025315402006689

Hirth HF, Klikoff LG, Harper KT (1973) Seagrasses at Khor Umaira, Peoples Democratic Republic of Yemen with reference to their role in diet of green turtle, Chelonia mydas. Fish Bull 71:1093-1097

Holloway-Adkins KG, Hanisak MD (2017) Macroalgal foraging preferences of juvenile green turtles (Chelonia mydas) in a warm temperate/subtropical transition zone. Mar Biol 164:161. https ://doi.org/10.1007/s00227-017-3191-0

Howell LN, Reich KJ, Shaver DJ, Landry AM Jr, Gorga CC (2016) Ontogenetic shifts in diet and habitat of juvenile green sea turtles in the northwestern Gulf of Mexico. Mar Ecol Prog Ser 559:217229. https://doi.org/10.3354/meps 11897

Jiménez A, Pingo S, Alfaro-Shigueto J, Mangel JC, Hooker Y (2017) Feeding ecology of the green turtle Chelonia mydas in northern Peru. Lat Am J Aquat Res 45:585-596. https://doi.org/10.3856/ vol45-issue3-fulltext-8

Jones TT, Seminoff JA (2013) Feeding biology: advances from fieldbased observations, physiological studies, and molecular techniques. In The Biology of Sea Turtles, Volume III (pp 228-265). CRC Press.

Karaa S, Bradai MN, Jribi I, Bouain A (2012) The occurrence of the green sea turtle Chelonia mydas, in the Gulf of Gabes (Tunisia). Vie Milieu 62:1-6

Klein CJ, Beher J, Chaloupka M, Hamann M, Limpus C, Possingham HP (2017) Prioritization of marine turtle management projects: a protocol that accounts for threats to different life history stages. Conserv Lett 10:547-554. https://doi.org/10.1111/conl.12324

Lazar B, Žuljević A, Holcer D (2010) Diet composition of a green turtle, Chelonia mydas, from the Adriatic Sea. Nat Croat 19:263-271

Lemons G, Lewison R, Komoroske L, Gaos A, Lai C, Dutton P, Eguchi T, LeRoux R, Seminoff JA (2011) Trophic ecology of green sea turtles in a highly urbanized bay: insights from stable isotopes and mixing models. J Exp Mar Biol Ecol 405:25-32. https://doi. org/10.1016/j.jembe.2011.05.012
León YM, Bjorndal KA (2002) Selective feeding in the hawksbill turtle, an important predator in coral reef ecosystems. Mar Ecol Prog Ser 245:249-258. https://doi.org/10.3354/meps245249

Letessier TB, Bouchet P, Reisser J, Meeuwig JJ (2014) Baited videography reveals remote foraging and migration behaviour of sea turtles. Mar Biodiv. https://doi.org/10.1007/s12526-014-0287-3

Limpus CJ, Limpus DJ (2000) Mangroves in the Diet of Chelonia mydas in Queensland, Australia. Mar Turtle Newsl 89:13-15

Limpus CJ, Reed PC (1985) Green sea turtles stranded by cyclone Kathy on the South-Western Coast of the Gulf of Carpentaria. Wildl Res 12:523-533. https://doi.org/10.1071/WR9850523

Limpus CJ, Couper PJ, Read MA (1994) The green turtle, Chelonia mydas, in Queensland: population structure in a warm temperature feeding area. Memoirs Queensland Museum Brisbane 35:139-154

López-Mendilaharsu M, Gardner SC, Seminoff JA, Riosmena-Rodriguez R (2005) Identifying critical foraging habitats of the green turtle (Chelonia mydas) along the Pacific coast of the Baja California peninsula, Mexico. Aquatic Conserv: Mar Freshw Ecosyst 15:259-269. https://doi.org/10.1002/aqc.676

MacArthur RH, Pianka ER (1966) On optimal use of a patchy environment. Am Nat 100(916):603-609. https://doi.org/10.1086/28245 4

Machovsky-Capuska GE, Andrades R, Santos RG (2020) Debris ingestion and nutritional niches in estuarine and reef green turtles. Mar Pollut Bull 153:110943. https://doi.org/10.1016/j.marpo lbul.2020.110943

Mackas DL, Batten S, Trudel M (2007) Effects on zooplankton of a warmer ocean: recent evidence from the Northeast Pacific. Prog Oceanog 75:223-252. https://doi.org/10.1016/j.pocea n.2007.08.010

Margaritoulis D, Teneketzis K (2003) Identification of a developmental habitat of the green turtle in Lakonikos Bay, Greece. In: Margaritoulis A, Demetropoulos A (eds) Proceedings of the First Mediterranean Conference on Marine Turtles. Barcelona Convention-Bern Convention-Bonn Convention (CMS), Nicosia, Cyprus, p 170-175

Matich P, Heithaus MR, Layman CA (2011) Contrasting patterns of individual specialization and trophic coupling in two marine apex predators. J Anim Ecol 80:294-305. https://doi.org/10.111 1/j.1365-2656.2010.01753.x

Mazaris AD, Schofield G, Gkazinou C, Almpanidou V, Hays GC (2017) Global sea turtle conservation successes. Sci Adv 3:e1600730. https://doi.org/10.1126/sciadv.1600730

McKenzie L, Nordlund LM, Jones BL, Cullen-Unsworth LC, Roelfsema CM, Unsworth RFK (2020) The global distribution of seagrass meadows. Environ Res Lett. https://doi.org/10.1088/17489326/ab7d06

Miller TW, Brodeur RD, Rau G, Omori K (2010) Prey dominance shapes trophic structure of the northern California Current pelagic food web: evidence from stable isotopes and diet analysis. Mar Ecol Prog Ser 420:15-26. https://doi.org/10.3354/meps0 8876

Monzón-Argüello C, Cardona L, Calabuig P, Camacho M, CrespoPicazo JL, García-Párraga D, Mayans S, Luzardo OP, Orós J, Varo-Cruz N (2018) Supplemental feeding and other anthropogenic threats to green turtles (Chelonia mydas) in the Canary Islands. Science Total Env 621:1000-1011. https://doi. org/10.1016/j.scitotenv.2017.10.126

Mortimer JA (1981) The feeding ecology of the West Caribbean green turtle (Chelonia mydas) in Nicaragua. Biotropica 49-58. https:// doi.org/10.2307/2387870

Mortimer JA, Esteban N, Guzman AN, Hays GC (2020) Estimates of sea turtle nesting populations in the south-western Indian Ocean indicate the importance of the Chagos Archipelago. Oryx 54:332-343. https://doi.org/10.1017/S0030605319001108 
Nagaoka SM, Martins AS, Santos RG, Tognella MMP, de Oliveira Filho EC, Seminoff JA (2012) Diet of juvenile green turtles (Chelonia mydas) associating with artisanal fishing traps in a subtropical estuary in Brazil. Mar Biol 159:573-581. https://doi. org/10.1007/s00227-011-1836-y

NCAR (2014) The Climate Data Guide: SST Data Sets: Overview \& Comparison Table. National Centre for Atmospheric Research Staff (Eds). Last modified 01 May 2014. https://climatedataguid e.ucar.edu/climate-data/sst-data-sets-overview-comparison-table . Accessed 4 May 2020.

NCAR (2015) International Comprehensive Ocean-Atmosphere Data Set (ICOADS) Release 2.5. https://rda.ucar.edu/datasets/\%20ds5 40.1. Accessed 4 May 2020.

NOAA (2020) Cold and warm episodes by season, El Niño / Southern Oscillation (ENSO): Historical El Niño / La Niña episodes (1950-present). Climate Prediction Centre https://origin.cpc. ncep.noaa.gov/products/analysis_monitoring/ensostuff/ONI_ v5.php. Accessed 30 April 2020

O'Connor MI, Bruno JF, Gaines SD, Halpern BS, Lester SE, Kinlan BP, Weiss JM (2007) Temperature control of larval dispersal and the implications for marine ecology, evolution, and conservation. Proc Nat Acad Sci 104:1266-1271. https://doi. org/10.1073/pnas.0603422104

Özdilek YP, Akdeniz B, Firat AR, Balkan EÝ, Gürsoy S, Sönmez B, Erduðan H (2015) Green turtles (Chelonia mydas) feeding on invasive algae Caulerpa taxifolia in Turkey. Russ J Herpetol 22:139-142

Parker DM, Dutton PH, Balazs GH (2011) Oceanic diet and distribution of haplotypes for the green turtles, Chelonia mydas, in the Central North Pacific. Pac Sci 65:419-431. https://doi. org/10.2984/65.4.419

Pearson RM, van de Merwe JP, Limpus CJ, Connolly RM (2017) Realignment of sea turtle isotope studies needed to match conservation priorities. Mar Ecol Prog Ser 583:259-271. https:// doi.org/10.3354/meps12353

Phillips S, US DOC/NOAA/NESDIS, National Oceanographic Data Centre (2012) AVHRR Pathfinder version 5.0 global $4 \mathrm{~km}$ sea surface temperature (SST) day-night monthly and yearly averages for 1985-2009 (NODC Accession 0077816) (Version 2.3). Accessed 17 October 2018

Pinaud D, Cherel Y, Weimerskirch H (2005) Effect of environmental variability on habitat selection, diet, provisioning behaviour and chick growth in yellow-nosed albatrosses. Mar Ecol Prog Ser 298:295-304. https://doi.org/10.3354/meps298295

Piovano S, Batibasaga A, Ciriyawa A, LaCasella EL, Dutton PH (2019) Mixed stock analysis of juvenile green turtles aggregating at two foraging grounds in Fiji reveals major contribution from the American Samoa Management Unit. Sci Rep 9:3150. https://doi.org/10.1038/s41598-019-39475-w

Piovano S, Lemons GE, Ciriyawa A, Batibasaga A, Seminoff JA (2020) Diet and recruitment of green turtles in Fiji, South Pacific, inferred from in-water capture and stable isotope analysis. Mar Ecol Prog Ser 640:201-213. https://doi.org/10.3354/ meps 13287

Price JT, Paladino FV, Lamont MM, Witherington BE, Bates ST, Soule $\mathrm{T}$ (2017) Characterization of the juvenile green turtle (Chelonia mydas) microbiome throughout an ontogenetic shift from pelagic to neritic habitats. PLoS ONE 12(5):e0177642. https:// doi.org/10.1371/journal.pone.0177642

Prior B, Booth DT, Limpus CJ (2016) Investigating diet and diet switching in green turtles (Chelonia mydas). Aust J Zool 63:365375. https://doi.org/10.1071/ZO15063

Quiñones J, Carman VG, Zeballos J, Purca S, Mianzan H (2010) Effects of El Niño-driven environmental variability on black turtle migration to Peruvian foraging grounds. Hydrobiologia 645:69-79. https://doi.org/10.1007/s10750-010-0225-8
R Core Team (2017) R: A Language and Environment for Statistical Computing. R Foundation for Statistical Computing, Vienna, Austria (https://www.R-project.org/).

Rasheed MA, Unsworth RK (2011) Long-term climate-associated dynamics of a tropical seagrass meadow: implications for the future. Mar Ecol Prog Ser 422:93-103. https://doi.org/10.3354/ meps08925

Read MA, Limpus CJ (2002) The green turtle, Chelonia mydas, in Queensland: feeding ecology of immature turtles in Moreton Bay, southeastern Queensland. Mem Queensl Mus 48:207-214

Rees AF, Alfaro-Shigueto J, Barata PC, Bjorndal KA, Bolten AB, Bourjea J, Broderick AC, Campbell LM, Cardona L, Carreras C, Casale P (2016) Are we working towards global research priorities for management and conservation of sea turtles? Endang Species Res 31:337-382. https://doi.org/10.3354/esr00801

Reich KJ, Bjorndal KA, Bolten AB (2007) The 'lost years' of green turtles: using stable isotopes to study cryptic lifestages. Biol Lett 3:712-714. https://doi.org/10.1098/rsbl.2007.0394

Reich KJ, Bjorndal KA, Martínez del Rio C (2008) Effects of growth and tissue type on the kinetics of ${ }^{13} \mathrm{C}$ and ${ }^{15} \mathrm{~N}$ incorporation in a rapidly growing ectotherm. Oecologia 155:651-663. https://doi. org/10.1007/s00442-007-0949-y

Reisser J, Proietti M, Sazima I, Kinas P, Horta P, Secchi E (2013) Feeding ecology of the green turtle (Chelonia mydas) at rocky reefs in western South Atlantic. Mar Biol 160:3169-3179. https ://doi.org/10.1007/s00227-013-2304-7

Riosmena-Rodriguez R, Talavera-Saenz AL, Hinojosa-Arango G, LaraUc M, Gardner S (2011) The foraging ecology of the green turtle in the Baja California peninsula: health issues. In: Smigorski (ed) Health management: different approaches and solutions: BoD-Books on Demand. London, UK, p 477-498. https://doi. org/10.5772/836

Roche DC (2016) Trophic ecology of green turtles (Chelonia mydas) from Dry Tortugas National Park, Florida. MS thesis, Nova Southeastern University, Florida, USA

Russell DJ, Balazs GH (2009) Dietary shifts by green turtles (Chelonia mydas) in the Kāne 'ohe Bay region of the Hawaiian Islands: a 28-year study. Pac Sci 63:181-192. https://doi. org/10.2984/049.063.0202

Russell DJ, Balazs GH (2015) Increased use of non-native algae species in the diet of the Green Turtle (Chelonia mydas) in a primary pasture ecosystem in Hawaii. Aquat Ecosyst Health Manage 18:342-346. https://doi.org/10.1080/14634988.2015.1027140

Sampson L, Giraldo A, Payán LF, Amorocho DF, Ramos MA, Seminoff JA (2018) Trophic ecology of green turtle Chelonia mydas juveniles in the Colombian Pacific. J Mar Biol Assoc UK 98:1817-1829. https://doi.org/10.1017/S0025315417001400

Santos RG, Martins AS, da Nobrega FJ, Horta PA, Pinheiro HT, Torezani E, Baptistotte C, Seminoff JA, Balazs GH, Work TM (2011) Coastal habitat degradation and green sea turtle diets in Southeastern Brazil. Mar Pollut Bull 62:1297-1302. https://doi. org/10.1016/j.marpolbul.2011.03.004

Santos RG, Martins AS, Batista MB, Horta PA (2015) Regional and local factors determining green turtle Chelonia mydas foraging relationships with the environment. Mar Ecol Prog Ser 529:265277. https://doi.org/10.3354/meps11276

Schofield G, Katselidis KA, Dimopoulos P, Pantis JD, Hays GC (2006) Behaviour analysis of the loggerhead sea turtle Caretta caretta from direct in-water observation. Endang Species Res 2:71-79. https://doi.org/10.3354/esr002071

Seminoff JA (2004) Chelonia mydas. IUCN Red List of Threatened Species 2004: e.T4615A11037468. https://doi.org/10.2305/ IUCN.UK.2004.RLTS.T4615A11037468.en. Downloaded 15 May 2020 
Seminoff JA, Resendiz A, Nichols WJ (2002) Diet of East Pacific green turtles (Chelonia mydas) in the central Gulf of California, Mexico. J Herpetol 36:447-453. https://doi.org/10.2307/1566189

Seminoff JA, Jones TT, Marshall GJ (2006) Underwater behaviour of green turtles monitored with video-time-depth recorders: what's missing from dive profiles? Mar Ecol Prog Ser 322:269-280. https://doi.org/10.3354/meps322269

Shimada T, Aoki S, Kameda K, Hazel J, Reich K, Kamezaki N (2014) Site fidelity, ontogenetic shift and diet composition of green turtles Chelonia mydas in Japan inferred from stable isotope analysis. Endang Species Res 25:151-164. https://doi.org/10.3354/ esr00616

Shimada T, Limpus CJ, Hamann M, Bell I, Esteban N, Groom R, Hays GC (2020) Fidelity to foraging sites after long migrations. J Anim Ecol 89:1008-1016. https://doi.org/10.1111/1365-2656.13157

Silva BM, Bugoni L, Almeida BA, Giffoni BB, Alvarenga FS, Brondizio LS, Becker JH (2017) Long-term trends in abundance of green sea turtles (Chelonia mydas) assessed by non-lethal capture rates in a coastal fishery. Ecol Ind 79:254-264. https://doi. org/10.1016/j.ecolind.2017.04.008

Souza JL (2019) Caracterização da dieta e ingestão de resíduos antropogênicos pela tartaruga-verde (Chelonia mydas) em Ubatuba-SP e Florianópolis-SC, Brasil. PhD thesis, Universidade de São Paulo, Brazil

Stokes HJ, Mortimer JA, Hays GC, Unsworth RKF, Laloë J-O, Esteban $\mathrm{N}$ (2019) Green turtle diet is dominated by seagrass in the Western Indian Ocean. Mar Biol 166:135. https://doi.org/10.1007/ s00227-019-3584-3

Stringell TB, Clerveaux WV, Godley BJ, Kent FEA, Lewis EDG, Marsh JE, Phillips Q, Richardson PB, Sanghera A, Broderick AC (2016) Taxonomic distinctness in the diet of two sympatric marine turtle species. Mar Ecol 37:1036-1049. https://doi. org/10.1111/maec. 12349

Thomson JA, Heithaus MR (2014) Animal-borne video reveals seasonal activity patterns of green sea turtles and the importance of accounting for capture stress in short-term biologging. $\mathrm{J}$ Exp Mar Biol Ecol 450:15-20. https://doi.org/10.1016/j.jembe .2013 .10 .020

Thomson JA, Whitman ER, Garcia-Rojas MI, Bellgrove A, Ekins M, Hays GC, Heithaus MR (2018) Individual specialization in a migratory grazer reflects long-term diet selectivity on a foraging ground: implications for isotope-based tracking. Oecologia 188:429-439. https://doi.org/10.1007/s00442-018-4218-z

Toggweiler JR, Russell J (2008) Ocean circulation in a warming climate. Nature 451:286-288. https://doi.org/10.1038/nature06590

Trevathan-Tackett SM, Macreadie PI, Sanderman J, Baldock J, Howes JM, Ralph PJ (2017) A global assessment of the chemical recalcitrance of seagrass tissues: implications for long-term carbon sequestration. Front Plant Sci 8:925. https://doi.org/10.3389/ fpls.2017.00925

Turner Tomaszewicz CN, Seminoff JA, Avens L, Goshe LR, RguezBaron JM, Peckham SH, Kurle CM (2018) Expanding the coastal forager paradigm: long-term pelagic habitat use by green turtles Chelonia mydas in the eastern Pacific Ocean. Mar Ecol Prog Ser 587:217-234. https://doi.org/10.3354/meps12372

UNEP-WCMC, Short FT (2018) Global distribution of seagrasses (version 6.0). Sixth update to the data layer used in Green and Short
(2003). Cambridge (UK): UN Environment World Conservation Monitoring Centre. Downloaded from https://data.unep-wcmc. org/datasets/7. Accessed 13 Nov 2018

Unsworth RKF, McKenzie LJ, Collier CJ, Cullen-Unsworth LC, Duarte CM, Eklöf JS, Jarvis JC, Jones BL, Nordlund LM (2019) Global challenges for seagrass conservation. Ambio 48:801. https://doi. org/10.1007/s13280-018-1115-y

Vander Zanden HB, Arthur KE, Bolten AB, Popp BN, Lagueux CJ, Harrison E, Campbell CL, Bjorndal KA (2013) Trophic ecology of a green turtle breeding population. Mar Ecol Prog Ser 476:237-249. https://doi.org/10.3354/meps10185

Vélez-Rubio GM, Cardona L, López-Mendilaharsu M, Souza GM, Carranza A, González-Paredes D, Tomás J (2016) Ontogenetic dietary changes of green turtles (Chelonia mydas) in the temperate southwestern Atlantic. Mar Biol 163:57. https://doi.org/10.1007/ s00227-016-2827-9

Vélez-Rubio GM, Teryda N, Asaroff PE, Estrades A, Rodriguez D, Tomás J (2018) Differential impact of marine debris ingestion during ontogenetic dietary shift of green turtles in Uruguayan waters. Mar Pollut Bull 127:603-611. https://doi.org/10.1016/j. marpolbul.2017.12.053

Wallace BP, DiMatteo AD, Hurley BJ, Finkbeiner EM, Bolten AB, Chaloupka MY, Hutchinson BJ, Abreu-Grobois FA, Amorocho D, Bjorndal KA, Bourjea J et al. (2010) Regional management units for marine turtles: a novel framework for prioritizing conservation and research across multiple scales. PLoS One 5(12). https://doi.org/10.1371/journal.pone.0015465

Wedemeyer-Strombel KR, Balazs GH, Johnson JB, Peterson TD, Wicksten MK, Plotkin PT (2015) High frequency of occurrence of anthropogenic debris ingestion by sea turtles in the North Pacific Ocean. Mar Biol 162:2079-2091. https://doi.org/10.1007/s0022 7-015-2738-1

Whiting SD, Guinea ML, Limpus CJ, Fomiatti K (2007) Blood chemistry reference values for two ecologically distinct populations of foraging green turtles, eastern Indian Ocean. Comp Clin Path 16:109-118. https://doi.org/10.1007/s00580-006-0646-y

Whiting SD, Macrae I, Thorn R, Murray W, Whiting AU (2014) Sea turtles of the Cocos (Keeling) Islands, Indian Ocean. Raffles Bull Zool 30:168-183

Whitman ER, Heithaus MR, Barcia LG, Brito DN, Rinaldi C, Kiszka JJ (2019) Effect of seagrass nutrient content and relative abundance on the foraging behaviour of green turtles in the face of a marine plant invasion. Mar Ecol Prog Ser 628:171-182. https:// doi.org/10.3354/meps 13092

Womble JN, Sigler MF (2006) Seasonal availability of abundant, energy-rich prey influences the abundance and diet of a marine predator, the Steller sea lion Eumetopias jubatus. Mar Ecol Prog Ser 325:281-293. https://doi.org/10.3354/meps325281

Wotherspoon D, Burgin S (2016) Sex and ontogenetic dietary shift in Pogona barbata, the Australian eastern bearded dragon. Aust J Zool 64:14-20. https://doi.org/10.1071/ZO15019

Publisher's Note Springer Nature remains neutral with regard to jurisdictional claims in published maps and institutional affiliations. 